\title{
Structure and Density of Mo and Acid Sites in Mo-Exchanged H-ZSM5 Catalysts for Nonoxidative Methane Conversion
}

\author{
Richard W. Borry III, Young Ho Kim, Anne Huffsmith, Jeffrey A. Reimer, and \\ Enrique Iglesia*
}

Materials Sciences Division, E.O. Lawrence Berkeley National Laboratory, and Department of Chemical Engineering, University of California, Berkeley, California 94720

Received: March 12, 1999; In Final Form: May 7, 1999

\begin{abstract}
Mo/H-ZSM5 (1.0-6.3 wt \% Mo; $\mathrm{Mo} / \mathrm{Al}=0.11-0.68)$ catalysts for $\mathrm{CH}_{4}$ aromatization were prepared from physical mixtures of $\mathrm{MoO}_{3}$ and $\mathrm{H}-\mathrm{ZSM} 5(\mathrm{Si} / \mathrm{Al}=14.3)$. X-ray diffraction and elemental analysis of physical mixtures treated in air indicate that $\mathrm{MoO}_{x}$ species migrate onto the external ZSM5 surface at about $623 \mathrm{~K}$. Between 773 and $973 \mathrm{~K}, \mathrm{MoO}_{x}$ species migrate inside zeolite channels via surface and gas phase transport, exchange at acid sites, and react to form $\mathrm{H}_{2} \mathrm{O}$. The amount of $\mathrm{H}_{2} \mathrm{O}$ evolved during exchange and the amount of residual $\mathrm{OH}$ groups detected by isotopic equilibration with $\mathrm{D}_{2}$ showed that each Mo atom replaces one $\mathrm{H}^{+}$ during exchange. This stoichiometry and the requirement for charge compensation suggest that exchanged species consist of $\left(\mathrm{Mo}_{2} \mathrm{O}_{5}\right)^{2+}$ ditetrahedral structures interacting with two cation exchange sites. The proposed mechanism may provide a general framework to describe the exchange of multivalent cations onto $\mathrm{Al}$ sites in zeolites. As the Mo concentration exceeds that required to form a $\mathrm{MoO}_{x}$ monolayer on the external zeolite surface ( $\sim 4 \mathrm{wt} \%$ Mo for the H-ZSM5 used), Mo species sublime as $\left(\mathrm{MoO}_{3}\right)_{n}$ oligomers or extract $\mathrm{Al}$ from the zeolite framework to form inactive $\mathrm{Al}_{2}\left(\mathrm{MoO}_{4}\right)_{3}$ domains detectable by ${ }^{27} \mathrm{Al}$ NMR. These $\left(\mathrm{Mo}_{2} \mathrm{O}_{5}\right)^{2+}$ species reduce to form the active $\mathrm{MoC}_{x}$ species during the initial stages of $\mathrm{CH}_{4}$ conversion reactions. Optimum $\mathrm{CH}_{4}$ aromatization rates were obtained on catalysts with intermediate Mo contents $(\sim 0.4 \mathrm{Mo} / \mathrm{Al})$, because both $\mathrm{MoC}_{x}$ and acid sites are required to activate $\mathrm{CH}_{4}$ and to convert the initial $\mathrm{C}_{2} \mathrm{H}_{4}$ products into $\mathrm{C}_{6+}$ aromatics favored by thermodynamics.
\end{abstract}

\section{Introduction}

The selective conversion of natural gas to higher hydrocarbons and aromatics remains an important industrial challenge. The discovery of catalytic $\mathrm{CH}_{4}$ aromatization on $\mathrm{Mo} / \mathrm{H}-\mathrm{ZSM} 5^{1}$ was followed by several reports of near-equilibrium $\mathrm{CH}_{4}$ conversions at $973 \mathrm{~K}$ with high selectivity to benzene. ${ }^{2-4} \mathrm{CH}_{4}$ reaction rates increased with time on stream as dispersed $\mathrm{MoO}_{x}$ formed the active $\mathrm{MoC}_{x}$ species. ${ }^{3}$ Ethylene and ethane are formed on $\mathrm{MoC}_{x}$ sites as primary products and they convert to $\mathrm{C}_{6+}$ aromatics via oligomerization, cracking, and cyclization reactions. These reactions require chain growth and dehydrogenation steps that occur on Bronsted acid sites aided by hydrogen desorption sites provided by $\mathrm{MoC}_{x}$ species. The net reaction rate is limited by the rate of $\mathrm{CH}_{4}$ activation and by the approach to thermodynamic equilibrium of the overall methane aromatization reaction. ${ }^{3}$

In previous studies, Mo/H-ZSM5 catalysts were prepared by slurry or incipient wetness impregnation of H-ZSM5 with aqueous ammonium heptamolybdate (AHM; $\left.\left(\mathrm{NH}_{4}\right)_{6} \mathrm{Mo}_{7} \mathrm{O}_{24}\right)$ solutions, followed by treatment in air at $723-973 \mathrm{~K} .{ }^{1-4}$ Large aqueous molybdate ions do not exchange directly onto H-ZSM5 cation exchange sites during impregnation. ${ }^{5}$ Infrared spectroscopy and differential thermal analysis ${ }^{6}$ showed that AHM decomposed in air between $500-650 \mathrm{~K}$ to form $\mathrm{MoO}_{3}$ crystallites on the outer surface of zeolite crystals. ${ }^{7,8}$ At $773 \mathrm{~K}, \mathrm{MoO}_{3}$ infrared bands disappeared as $\mathrm{MoO}_{3}$ crystallites dispersed on the external surface of ZSM5 crystals and then migrated as

* Corresponding author. E-mail: iglesia@cchem.berkeley.edu.
$\left(\mathrm{MoO}_{3}\right)_{n}$ oligomers into zeolite channels. ${ }^{6}$ These authors concluded that $\mathrm{MoO}_{x}$ interacts with framework oxygens in H-ZSM5 at $973 \mathrm{~K}$ to form isolated monomolybdate species $\left(\mathrm{MoO}_{4}{ }^{2-}\right)$ based on the appearance of infrared bands for $\mathrm{Mo}=\mathrm{O}$ vibrations in tetrahedral $\mathrm{Mo}^{6+}$.

Surface migration of $\mathrm{MoO}_{x}$ onto H-ZSM5 can occur at high temperatures because lattice mobility within $\mathrm{MoO}_{3}$ becomes possible above its Tammann temperature $(534 \mathrm{~K}) .{ }^{9}$ Sublimation of $\mathrm{MoO}_{3}$ becomes detectable above $623-673 \mathrm{~K},{ }^{10}$ and $\mathrm{MoO}_{3}$ reaches a vapor pressure of $56 \mathrm{~Pa}$ at $973 \mathrm{~K}^{11}$ as $\left(\mathrm{MoO}_{3}\right)_{n}$ oligomers $(n=2-5) .{ }^{12} \mathrm{H}_{2} \mathrm{O}$ formed during decomposition of AHM precursors can form $\mathrm{MoO}_{2}(\mathrm{OH})_{2},{ }^{12,13}$ which has a vapor pressure of $4.9 \mathrm{~Pa}$ at $973 \mathrm{~K}^{11}$

As isolated $\mathrm{MoO}_{x}$ species migrate into zeolite channels via gas phase or surface diffusion, they react with $\mathrm{H}^{+}$atoms at exchange sites to form $\left(\mathrm{MoO}_{2}(\mathrm{OH})\right)^{+}$species, which can condense with another one to form a $\left(\mathrm{Mo}_{2} \mathrm{O}_{5}\right)^{2+}$ dimer and $\mathrm{H}_{2} \mathrm{O}$ :

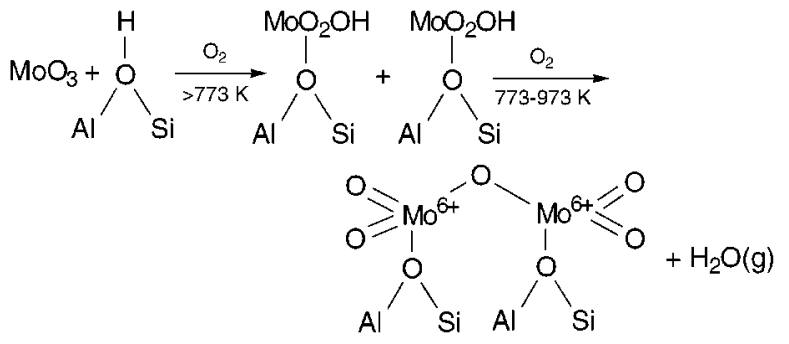

Throughout this report, we refer to these dimers as $\left(\mathrm{Mo}_{2} \mathrm{O}_{5}\right)^{2+}$ in spite of the fact that such cationic species are not known in 
solution, because it is customary to think of exchanged species in zeolites as cationic. The stable structural analog is the known $\left(\mathrm{Mo}_{2} \mathrm{O}_{7}\right)^{2-}$ anion, consisting of two Mo centers with tetrahedral symmetry, with two of the oxygen atoms residing at framework positions in ZSM5. $\left(\mathrm{MoO}_{2}(\mathrm{OH})\right)^{+}$species can also react with a zeolite $\mathrm{OH}$ group to form a $\left(\mathrm{MoO}_{2}\right)^{2+}$ cation bridging two acid sites and water, a structure previously proposed for the exchange of $\mathrm{MoO}_{2} \mathrm{Cl}_{2}$ onto $\mathrm{H}-\mathrm{Y}$ zeolite. ${ }^{14}$
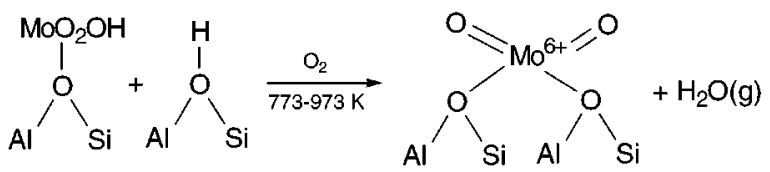

Similar condensation reactions of $\mathrm{OH}$ groups lead to the extraction of $\mathrm{Al}$ ions from the framework, with the formation of water and the disappearance of two Bronsted acid sites. In $\mathrm{Mo} / \mathrm{H}-\mathrm{ZSM} 5$, extraframework $\mathrm{Al}$ atoms form small domains of $\mathrm{Al}_{2} \mathrm{O}_{3}$ or $\mathrm{Al}_{2}\left(\mathrm{MoO}_{4}\right)_{3}$; the latter species were detected by ${ }^{27} \mathrm{Al}$ NMR in Mo/H-ZSM5 samples with high Mo content $(>10$ wt $\%) .{ }^{15}$

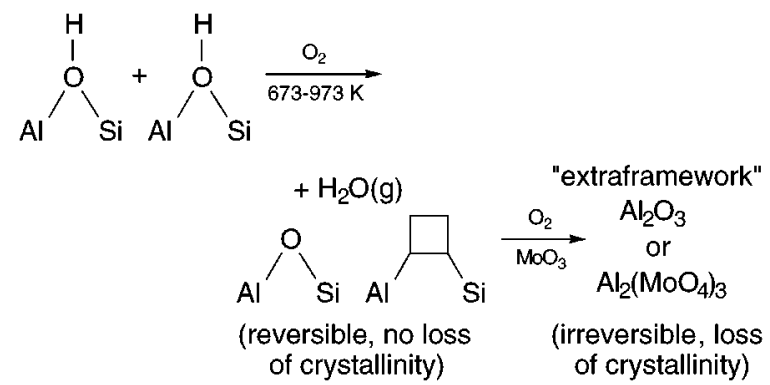

Impregnation or ion exchange of $\mathrm{H}-\mathrm{ZSM} 5$ with AHM solutions leads initially to external $\mathrm{MoO}_{3}$ crystals during treatment in air. Thus, it seemed possible to prepare $\mathrm{Mo} / \mathrm{H}$ ZSM5 via exchange from intimate mixtures of $\mathrm{MoO}_{3}$ and H-ZSM5 powders. This approach avoids AHM decomposition products $\left(\mathrm{N}_{2}, \mathrm{NH}_{3} \text {, and } \mathrm{H}_{2} \mathrm{O}\right)^{6}$, which interfere with measurements of the kinetics and the extent of exchange from the amount of water evolved during synthesis. Here, we report mechanistic details of the synthesis of $\mathrm{MoO}_{x} / \mathrm{H}-\mathrm{ZSM} 5$ from mixtures of $\mathrm{MoO}_{3}$ and $\mathrm{H}-\mathrm{ZSM} 5$ powders, the structure of the $\mathrm{MoO}_{x}$ species formed during exchange, and the role and density of $\mathrm{MoO}_{x}$ species and of Bronsted acid sites in alkane reactions.

\section{Experimental Section}

Catalyst Synthesis and Characterization. H-ZSM5 was prepared by aqueous exchange (repeated four times) of NaZSM5 (Zeochem, Si:Al = 14.3) with 1.0 $\mathrm{M} \mathrm{NH}_{4} \mathrm{NO}_{3}$ (Fisher) ( $\sim 10 \mathrm{~g} \mathrm{Na-ZSM5/L).} \mathrm{The} \mathrm{samples} \mathrm{were} \mathrm{dried} \mathrm{at} 400 \mathrm{~K}$ for 24 $\mathrm{h}$ and treated in dry air at $773 \mathrm{~K}$ for $24 \mathrm{~h}(10-15 \mathrm{~g}$ of cat., 50 $\left.\mathrm{cm}^{3} / \mathrm{min}\right)$. Mo/H-ZSM5 was prepared from physical mixtures of $\mathrm{MoO}_{3}$ (Johnson Matthey, 99.5\% purity) and H-ZSM5; these mixtures were ground together for about $0.1 \mathrm{~h}$ in an alumina mortar and pestle. Powder X-ray diffraction patterns were obtained in a Siemens Diffractometer D5000 using $\mathrm{Cu} \mathrm{K \alpha}$ radiation $(\lambda=1.5406 \AA$ ). Surface areas and pore volumes were obtained from $\mathrm{N}_{2}$ physisorption at its boiling point (Autosorb 6; Quantachrome, Inc.), after treating samples at $773 \mathrm{~K}$ for $1 \mathrm{~h}$ in flowing dry air (Medical grade, Praxair).

The effect of air treatment was examined using $\mathrm{MoO}_{3} / \mathrm{H}$ ZSM5 mixtures $(0.3 \mathrm{~g}, 0-8 \mathrm{wt} \% \mathrm{Mo})$ dried at $623 \mathrm{~K}$ for $24 \mathrm{~h}$ in $20 \% \mathrm{O}_{2} / \mathrm{Ar}\left(100 \mathrm{~cm}^{3} / \mathrm{min}\right.$, Praxair, $\left.>99.999 \%\right)$. Samples were heated at $10 \mathrm{~K} / \mathrm{min}$ to $973 \mathrm{~K}$ and $\mathrm{H}_{2} \mathrm{O}$ evolution rates were measured by mass spectrometry (Leybold Inficon, THP-TS200) using heated transfer lines $(373 \mathrm{~K})$ and $\mathrm{Ar}$ as an internal standard. Samples were held at $973 \mathrm{~K}$ for $0.5 \mathrm{~h}$ and then cooled to $300 \mathrm{~K}$. The number of residual $\mathrm{OH}$ groups in Mo/H-ZSM5 was measured from the evolution of $\mathrm{HD}$ and $\mathrm{H}_{2}$ by mass spectrometry as samples were heated from 300 to $873 \mathrm{~K}$ (10 $\mathrm{K} / \mathrm{min}, 2 \mathrm{~min}$ hold time $)$ in $5 \% \mathrm{D}_{2} / \mathrm{Ar}\left(100 \mathrm{~cm}^{3} / \mathrm{min}\right.$, Praxair, $>99.999 \%) .{ }^{16,17}$ Samples were then cooled to $300 \mathrm{~K}$ and the experiment was repeated using $5 \% \mathrm{H}_{2} / \mathrm{Ar}\left(100 \mathrm{~cm}^{3} / \mathrm{min}\right.$, Praxair, $>99.999 \%$ ) while measuring $\mathrm{HD}$ and $\mathrm{D}_{2}$ evolution rates. The Mo content was measured by atomic absorption (Galbraith Laboratories) after treatment in air at $973 \mathrm{~K}$.

${ }^{27} \mathrm{Al}$ NMR spectra were collected using a home-built 400 $\mathrm{MHz}$ spectrometer (9.1 T magnetic field) at $104.2 \mathrm{MHz}$ while spinning at $4 \mathrm{kHz} .{ }^{18}$ Samples were hydrated at room temperature by placing them in an empty desiccator containing liquid water. Hydration of $\mathrm{Al}$ sites weakens quadrupole interactions that broaden ${ }^{27} \mathrm{Al}$ NMR lines in H-ZSM5. ${ }^{19,20}$

Steady-State $\mathrm{CH}_{4}$ Aromatization on Mo/H-ZSM5. $\mathrm{CH}_{4}$ reactions were carried out at $950 \mathrm{~K}$ in a tubular reactor $(4 \mathrm{~mm}$ i.d.) with plug-flow hydrodynamics $\left(25 \mathrm{~cm}^{3} / \mathrm{min}, 1: 1 \mathrm{CH}_{4} / \mathrm{Ar}\right.$ (Praxair, >99.995\%)). Mo/H-ZSM5 catalysts $(1.0 \mathrm{~g})$ were loaded onto a porous quartz disk $(1.0 \mathrm{~cm}$ i.d.) located within this reactor. Temperatures were measured with a type $\mathrm{K}$ thermocouple located inside a quartz sheath in contact with the catalyst bed. The reactor effluent was sampled using transfer lines held at $400 \mathrm{~K},{ }^{21}$ and the reactant and product concentrations were measured by gas chromatography. ${ }^{22}$ Reported selectivities are defined as the percentage of the $\mathrm{CH}_{4}$ converted appearing as a given product. $\mathrm{CH}_{4}$ was used as the reference peak between the flame ionization and thermal conductivity detectors and $\mathrm{Ar}$ was used as an internal standard. The amount of carbon missing within the measured products $(1-10 \%)$ is reported as "carbon" in the results, but it includes carbon consumed to form $\mathrm{MoC}_{x}$ and condensable products remaining in zeolite channels or in transfer lines. The reported values for $\mathrm{CH}_{4}$ conversion, hydrocarbon yields, and carbon balances were reproducible within $\pm 0.5 \%$ (absolute), and the detection limits were 50 and 1 ppm for thermal conductivity and flame ionization detectors, respectively. Catalysts were treated in $20 \% \mathrm{O}_{2} / \mathrm{He}\left(100 \mathrm{~cm}^{3} / \mathrm{min}\right.$, Praxair, $>99.999 \%$ ) at $950 \mathrm{~K}$ for $2 \mathrm{~h}$ before catalytic reactions. ${ }^{23}$

\section{Results}

Catalytic $\mathrm{CH}_{4}$ Aromatization on Mo/H-ZSM5. $\mathrm{CH}_{4}$ reaction rates and selectivities measured on Mo/H-ZSM5 (4.0 wt $\%)$ prepared from $\mathrm{MoO}_{3} / \mathrm{H}-\mathrm{ZSM} 5$ mixtures (Figure 1) were similar to those reported on samples prepared by impregnation of H-ZSM5 with aqueous AHM (Table 1). ${ }^{3}$ During the initial activation $(\sim 1-2 \mathrm{~h}), \mathrm{CH}_{4}$ conversion reached about $20 \%$, but carbon, $\mathrm{H}_{2}, \mathrm{CO}_{2}, \mathrm{H}_{2} \mathrm{O}$, and $\mathrm{CO}$ were the most abundant initial products. After $2 \mathrm{~h}, \mathrm{CO}$ and $\mathrm{CO}_{2}$ were no longer detectable and the carbon selectivity was below $7 \%$. Benzene $(\sim 70 \%$ selectivity), toluene $(\sim 5 \%)$, ethylene $(4-8 \%)$, ethane $(2-4 \%)$, and naphthalene $(10-20 \%)$ were formed at $\mathrm{CH}_{4}$ conversions of $7-10 \%$. Propene and $o$-xylene were also detected in trace amounts ( $<2 \%$ selectivity). By comparison, a Mo/H-ZSM5 (2 wt \%) sample prepared by impregnation of H-ZSM5 with aqueous $\mathrm{AHM}^{3}$ gave $10 \% \mathrm{CH}_{4}$ conversion and $70 \%$ selectivity to benzene at $973 \mathrm{~K}$ (Table 1).

$\mathrm{MoO}_{3}$ Migration and Sublimation during Catalyst Synthesis. Our initial measurements of the rate of $\mathrm{MoO}_{x}$ migration from the rate of $\mathrm{H}_{2} \mathrm{O}$ evolution during treatment in air were influenced by $\mathrm{MoO}_{3}$ sublimation from the physical mixtures. Heating $\mathrm{MoO}_{3} / \mathrm{H}-\mathrm{ZSM} 5$ mixtures $(4.0 \mathrm{wt} \% \mathrm{Mo}$ ) from 300 to 
TABLE 1: Comparison of $\mathrm{CH}_{4}$ Aromatization on Mo/H-ZSM5 Prepared from Aqueous Impregnation of Molybdate Solution on $\mathrm{H}-\mathrm{ZSM} 5$ and Physical Mixture of $\mathrm{MoO}_{3} / \mathrm{H}-\mathrm{ZSM} 5$

\begin{tabular}{|c|c|c|c|c|c|c|c|c|}
\hline \multirow{2}{*}{$\begin{array}{l}\text { Mo content } \\
\text { (wt \%) }\end{array}$} & \multirow{2}{*}{$\begin{array}{l}\mathrm{Mo} / \mathrm{Al} \\
\text { atomic ratio }\end{array}$} & \multirow{2}{*}{$\begin{array}{l}\text { reaction } \\
\text { temp }(\mathrm{K})\end{array}$} & \multirow{2}{*}{$\begin{array}{c}\text { GHSV } \\
\left(\mathrm{h}^{-1}\right)\end{array}$} & \multirow{2}{*}{$\begin{array}{c}\mathrm{CH}_{4} \\
\text { conversion (\%) }\end{array}$} & \multirow[b]{2}{*}{$\mathrm{C}_{2} \mathrm{H}_{4}$} & \multicolumn{2}{|c|}{ selectivity (\%) } & \multirow{2}{*}{$\begin{array}{l}\text { solid } \\
\text { carbon }\end{array}$} \\
\hline & & & & & & $\mathrm{C}_{6} \mathrm{H}_{6}$ & $\mathrm{C}_{10} \mathrm{H}_{8}$ & \\
\hline $2.0^{a}$ & 0.37 & 973 & 800 & 10.0 & 3 & 70 & 20 & 5 \\
\hline $4.0^{b}$ & 0.42 & 950 & $750^{d}$ & 10.2 & 2 & 66 & 18 & 12 \\
\hline $4.3^{e}$ & 0.45 & 950 & $750^{d}$ & 1.7 & 17 & 27 & 4 & 52 \\
\hline
\end{tabular}

${ }^{a}$ Incipient wetness impregnation of AHM/H-ZSM5. ${ }^{3}{ }^{b}$ Physical mixture of $\mathrm{MoO}_{3} / \mathrm{H}-\mathrm{ZSM} 5$ (this study). $c$ "Vapor-exchanged" preparation method (this study, Figure 6). ${ }^{d}$ Space velocity was calculated assuming catalyst packed density of $0.5 \mathrm{~g} \mathrm{cat} . / \mathrm{cm}^{3}$ reactor volume.
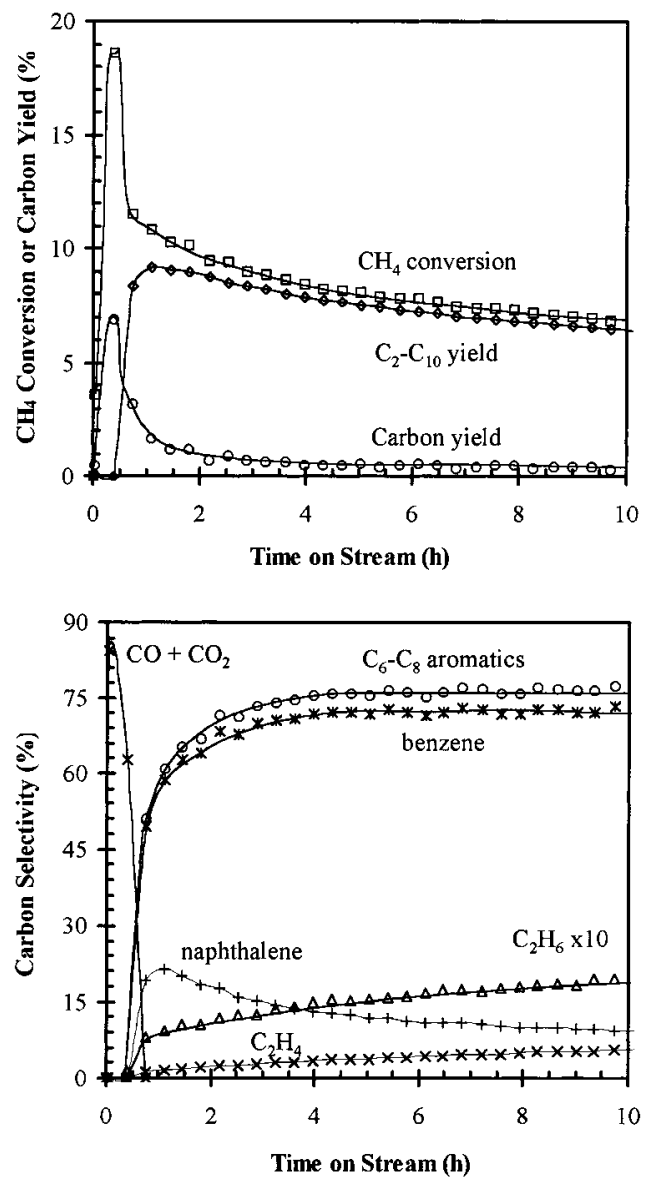

Figure 1. $\mathrm{CH}_{4}$ pyrolysis on 4 wt $\% \mathrm{Mo} / \mathrm{H}-\mathrm{ZSM} 5$, (a, top) $\mathrm{CH}_{4}$ conversion, $\mathrm{C}_{2}-\mathrm{C}_{10}$ hydrocarbon product yield, and solid carbon yield vs. time on stream, (b, bottom) carbon selectivity of gas-phase products vs time on stream $\left(1.0 \mathrm{~g}, 25 \mathrm{~cm}^{3} / \mathrm{min}, 50 \% \mathrm{CH}_{4} / \mathrm{Ar}, 105 \mathrm{kPa}, 950 \mathrm{~K}\right)$.

TABLE 2: Mo Content after Temperature-Programmed Oxidation of $\mathrm{MoO}_{3} / \mathrm{H}-\mathrm{ZSM} 5$ Mixtures $(\sim 4 \mathrm{wt} \% \mathrm{Mo}$, $0.3-1.0 \mathrm{~g}, 100 \mathrm{~cm}^{3} / \mathrm{min}, 20 \% \mathrm{O}_{2}$ in $\left.\mathrm{He}\right)$

\begin{tabular}{|c|c|c|c|}
\hline & temperature program & $\begin{array}{c}\text { Mo as prepared }{ }^{a} \\
\text { (wt \%) }\end{array}$ & $\begin{array}{l}\text { Mo after } \mathrm{TPO}^{b} \\
\text { (wt } \%)\end{array}$ \\
\hline I & 300 to $973 \mathrm{~K}(10 \mathrm{~K} / \mathrm{min})$ & 4.0 & 3.47 \\
\hline II & $\begin{array}{l}300 \text { to } 623 \mathrm{~K}(\text { hold } 24 \mathrm{~h}) \\
623 \text { to } 973 \mathrm{~K}(10 \mathrm{~K} / \mathrm{min})\end{array}$ & 4.0 & 3.60 \\
\hline III & $\begin{array}{l}300 \text { to } 623 \mathrm{~K} \text { (hold } 24 \mathrm{~h}) \\
623 \text { to } 773 \mathrm{~K}(10 \mathrm{~K} / \mathrm{min}, 48 \mathrm{~h}) \\
773 \text { to } 950 \mathrm{~K}(10 \mathrm{~K} / \mathrm{min}, 2 \mathrm{~h})\end{array}$ & 3.94 & 3.95 \\
\hline
\end{tabular}

${ }^{a}$ Based on amount of Mo added to physical mixture. ${ }^{b}$ Based on elemental analysis of oxidized sample.

$973 \mathrm{~K}$ (at $10 \mathrm{~K} / \mathrm{min}$ ) led to the sublimation of $13 \%$ of the Mo as $\left(\mathrm{MoO}_{3}\right)_{n}$ or $\mathrm{MoO}_{2}(\mathrm{OH})_{2}$ (Table 2, program I). The sublimed $\mathrm{MoO}_{x}$ appeared as small $\mathrm{MoO}_{3}$ crystallites on the walls after the heated sample. When $\mathrm{MoO}_{3} / \mathrm{H}-\mathrm{ZSM} 5$ mixtures were held at $623 \mathrm{~K}$ for $24 \mathrm{~h}$ in order to remove physisorbed $\mathrm{H}_{2} \mathrm{O}$ and to disperse $\mathrm{MoO}_{x}$ species onto the external zeolite surface,

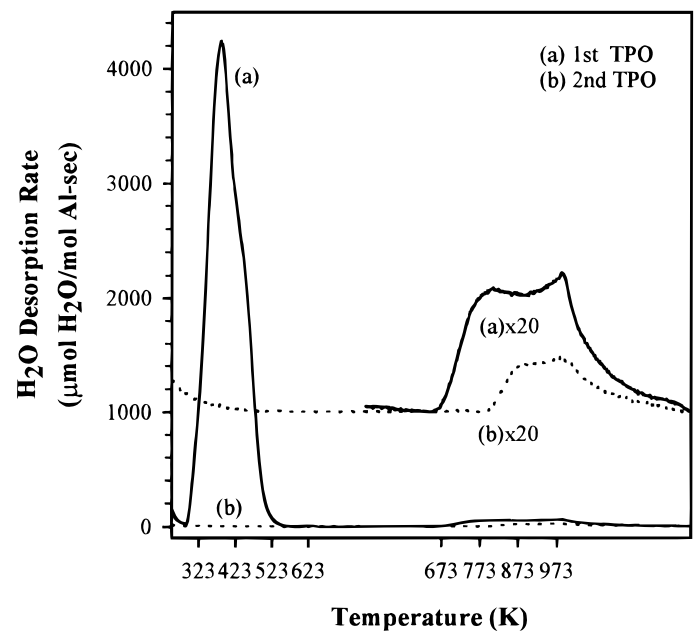

Figure 2. $\mathrm{H}_{2} \mathrm{O}$ desorption from $\mathrm{H}-\mathrm{ZSM} 5$ during first (a) and second (b) TPO. The sample was heated at $10 \mathrm{~K} / \mathrm{min}$ from 323 to $623 \mathrm{~K}$, held for $24 \mathrm{~h}$, then heated at $10 \mathrm{~K} / \mathrm{min}$ to $973 \mathrm{~K}\left(0.3 \mathrm{~g}, 100 \mathrm{~cm}^{3} / \mathrm{min}, 20 \%\right.$ $\left.\mathrm{O}_{2} / \mathrm{Ar}, 101 \mathrm{kPa}\right)$.

subsequent heating in air to $973 \mathrm{~K}$ led to Mo losses of less than $10 \%$ (Table 2, program II). The $\mathrm{H}_{2} \mathrm{O}$ evolved during exchange appeared as a well-defined peak between 623 and 973 $\mathrm{K}$ (as shown later in Figure 3). Holding at $773 \mathrm{~K}$ for $48 \mathrm{~h}$ during treatment in air (Table 2, program III) eliminated Mo loss $(<0.1 \%)$, apparently because $\mathrm{MoO}_{x}$ crystallites spread as strongly interacting layers with much lower vapor pressure than bulk $\mathrm{MoO}_{3}$. This method was used to prepare the Mo/H-ZSM5 samples used in the reaction studies (Figure 1, Table 1).

$\mathrm{H}_{2} \mathrm{O}$ Desorption during Oxidative Treatment of $\mathrm{MoO}_{3} /$ H-ZSM5 Mixtures. Figure 2 shows the $\mathrm{H}_{2} \mathrm{O}$ evolution rate during temperature-programmed oxidation (TPO) of H-ZSM5 (using program II in Table 2). The peak at 300-500 K corresponds to the desorption of water adsorbed on H-ZSM5 from ambient air $\left(2.62 \mathrm{~mol} \mathrm{H}_{2} \mathrm{O} / \mathrm{Al}\right)$. The smaller peak between 673 and $973 \mathrm{~K}$ corresponds to zeolite dealumination (eq 3) by loss of $\mathrm{OH}$ groups and extraction of $\mathrm{Al}$ atoms from tetrahedral framework positions. A previous thermogravimetric study of $\mathrm{H}-\mathrm{ZSM} 5$ reached similar conclusions. ${ }^{24}$ Figure $2 \mathrm{~b}$ shows $\mathrm{H}_{2} \mathrm{O}$ evolution rates during a second TPO after cooling the sample in dry $20 \% \mathrm{O}_{2} / \mathrm{Ar}\left(100 \mathrm{~cm}^{3} / \mathrm{min}\right)$ to room temperature. The physisorbed water peak is no longer detected and the dealumination peak was smaller and it appeared at higher temperature, indicating that the zeolite structure was stabilized against further dealumination by the initial treatment. The number of $\mathrm{OH}$ groups desorbed as $\mathrm{H}_{2} \mathrm{O}$ during the first and second treatments corresponds to 0.23 and $0.06 \mathrm{H} / \mathrm{Al}$, respectively.

$\mathrm{H}_{2} \mathrm{O}$ evolution during TPO of a $\mathrm{MoO}_{3} / \mathrm{H}-\mathrm{ZSM}$ 5 physical mixture $(4.5 \mathrm{wt} \% \mathrm{Mo})^{25}$ shows that the amount of physisorbed $\mathrm{H}_{2} \mathrm{O}$ is slightly smaller than on H-ZSM5 (1.80 mol $\mathrm{H}_{2} \mathrm{O} / \mathrm{Al}$ ), but the second peak is much larger (Figure 3 ). This reflects the anchoring of Mo at cation exchange sites to form Mo species containing $\mathrm{OH}$ groups and the subsequent condensation of these 


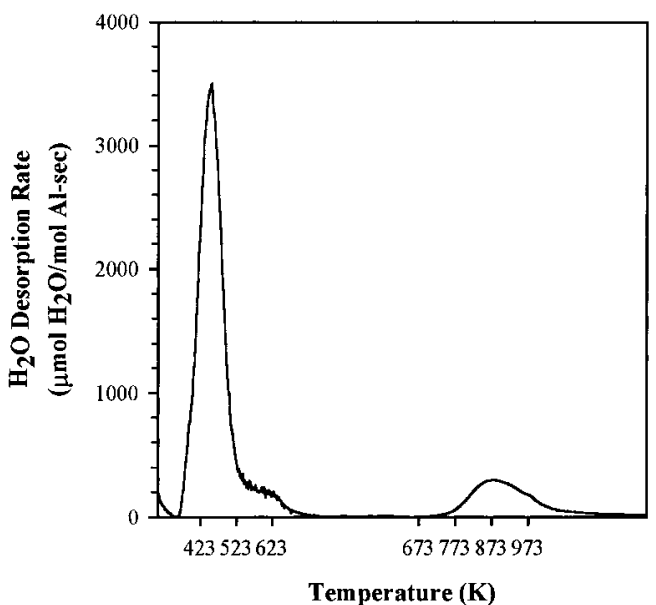

Figure 3. $\mathrm{H}_{2} \mathrm{O}$ desorption from $\mathrm{MoO}_{3} / \mathrm{H}-\mathrm{ZSM} 5$ mixture (4 wt $\% \mathrm{Mo}$ ) during TPO. The sample was heated at $10 \mathrm{~K} / \mathrm{min}$ from 323 to $623 \mathrm{~K}$, held for $24 \mathrm{~h}$, then heated at $10 \mathrm{~K} / \mathrm{min}$ to $973 \mathrm{~K}\left(0.3 \mathrm{~g}, 100 \mathrm{~cm}^{3} / \mathrm{min}\right.$, $20 \% \mathrm{O}_{2} / \mathrm{Ar}, 101 \mathrm{kPa}$ ).

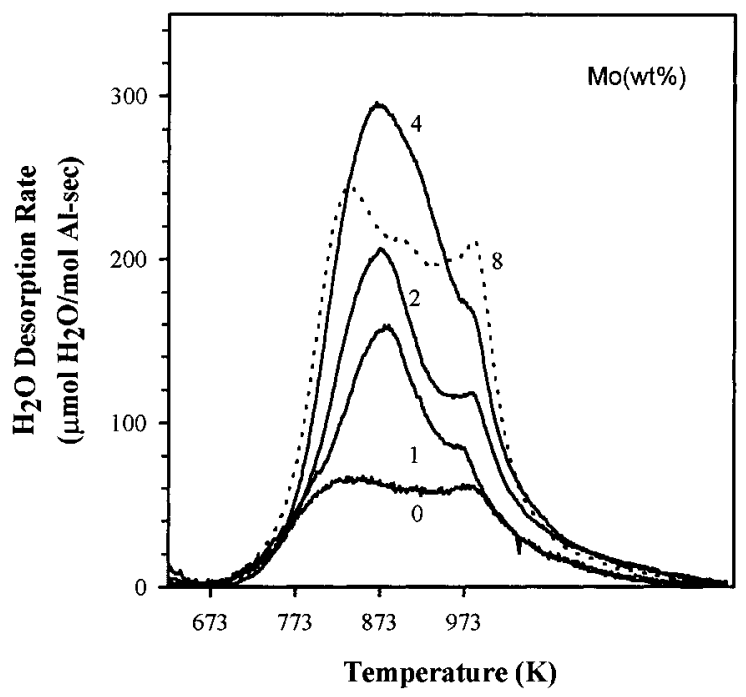

Figure 4. $\mathrm{H}_{2} \mathrm{O}$ desorption between 623 and $973 \mathrm{~K}$ from $\mathrm{MoO}_{3} /$ H-ZSM5 mixtures with varying Mo initial concentration $(0.3 \mathrm{~g}, 100$ $\mathrm{cm}^{3} / \mathrm{min}, 20 \% \mathrm{O}_{2} / \mathrm{Ar}, 101 \mathrm{kPa}$, heat at $10 \mathrm{~K} / \mathrm{min}$ ).

$\mathrm{OH}$ groups with those in H-ZSM5 or in neighboring Mo cations (eqs 1 or 2). The small difference in $\mathrm{H}_{2} \mathrm{O}$ desorption rates below $623 \mathrm{~K}$ between $\mathrm{H}$-ZSM5 (Figure 2) and $\mathrm{MoO}_{3} / \mathrm{H}-\mathrm{ZSM} 5$ mixtures (Figure 3) is caused by $\mathrm{OH}$ groups bound to $\mathrm{MoO}_{3}$, and not by Mo exchange. This conclusion is confirmed by the observation that $\mathrm{H}_{2} \mathrm{O}$ evolution rates between 623 and $773 \mathrm{~K}$ did not depend on Mo loading (Figures 4 and 14), suggesting that Mo cations migrate into channels and exchange only above $773 \mathrm{~K}$, as also proposed by others. ${ }^{26}$ Figure 4 shows that the amount of $\mathrm{H}_{2} \mathrm{O}$ formed between 773 and $973 \mathrm{~K}$ increased with increasing Mo content. Some Mo sublimes from mixtures with more than 2 wt \% Mo (Table 3) when treated by program II (Table 2); this was confirmed by elemental analyses before and after air treatment and by the $\mathrm{MoO}_{3}$ residue formed at the exit of the treatment cell.

The number of $\mathrm{H}_{2} \mathrm{O}$ molecules (per $\mathrm{Al}$ ) formed during air treatment is shown in Table 4. If the loss of $\mathrm{OH}$ groups via recombination and $\mathrm{Al}$ extraction from framework positions occurred to the same extent in Mo/H-ZSM5 and H-ZSM5 samples, $\mathrm{H}_{2} \mathrm{O}$ desorption values on Mo/H-ZSM5 can be corrected by subtracting the amount of $\mathrm{H}_{2} \mathrm{O}$ desorbed from pure H-ZSM5 (0.23 H/Al, Table 4). These corrected values are reported as $\mathrm{H} / \mathrm{Al}_{\mathrm{F}}\left(\mathrm{Al}_{\mathrm{F}}=\right.$ framework aluminum $)$. This assump-
TABLE 3: Mo Content Measured by Atomic Absorption Spectrometry before and after Oxidation of $\mathrm{MoO}_{3} / \mathrm{H}-\mathrm{ZSM} 5$ Physical Mixtures of Varying Mo Concentration (Temperature Program II in Table $2,0.3 \mathrm{~g}, 100 \mathrm{~cm}^{3} / \mathrm{min}$, $20 \% \mathrm{O}_{2}$ in $\mathrm{He}$ )

\begin{tabular}{ccccc}
\hline $\begin{array}{c}\text { target Mo } \\
\text { content } \\
\text { (wt \%) }\end{array}$ & $\begin{array}{c}\text { analyzed Mo } \\
\text { content in physical } \\
\text { mixture (wt \%) }\end{array}$ & $\begin{array}{c}\text { Mo/Al } \\
\text { before TPO }\end{array}$ & $\begin{array}{c}\text { analyzed Mo } \\
\text { content after } \\
\text { TPO (wt \%) }\end{array}$ & $\begin{array}{c}\text { Mo/Al } \\
\text { after TPO }\end{array}$ \\
\hline 1 & 1.1 & 0.11 & 1.0 & 0.11 \\
2 & 2.2 & 0.22 & 2.0 & 0.20 \\
4 & 4.0 & 0.42 & 3.6 & 0.37 \\
8 & 7.9 & 0.87 & 6.3 & 0.68
\end{tabular}

TABLE 4: $\mathrm{H}_{2} \mathrm{O}$ Desorption (TPO Program II, $0.3 \mathrm{~g}, 100$ $\mathrm{cm}^{3} / \mathrm{min}, 20 \% \mathrm{O}_{2}$ in $\left.\mathrm{He}\right)$ and Isotopic Exchange $(10 \mathrm{~K} / \mathrm{min}$, $100 \mathrm{~cm}^{3} / \mathrm{min}, 5 \%\left(\mathrm{D}_{2}\right.$ or $\left.\mathrm{H}_{2}\right)$ in $\left.\mathrm{Ar}\right)$ of $\mathrm{MoO}_{3} / \mathrm{H}-\mathrm{ZSM}$ Mixtures

\begin{tabular}{|c|c|c|c|c|c|c|c|}
\hline \multirow{2}{*}{$\begin{array}{l}\text { Mo content } \\
\text { after TPO } \\
(\mathrm{wt} \%)\end{array}$} & \multirow{2}{*}{$\begin{array}{c}\mathrm{Mo} / \mathrm{Al} \\
\text { ratio }\end{array}$} & \multicolumn{3}{|c|}{$\mathrm{H}_{2} \mathrm{O}$ desorption } & \multicolumn{2}{|c|}{ residual $\mathrm{H}$ content } & \multirow{2}{*}{$\begin{array}{c}\mathrm{H} \\
\text { balance } \\
\mathrm{H} / \mathrm{Al}\end{array}$} \\
\hline & & $\mathrm{H} / \mathrm{Al}^{a}$ & $\mathrm{H} / \mathrm{Al}_{\mathrm{F}}^{b}$ & $\overline{\mathrm{H} / \mathrm{Mo}^{c}}$ & $\mathrm{H} / \mathrm{Al}^{d}$ & $\mathrm{D} / \mathrm{Al}^{e}$ & \\
\hline 0 & 0 & 0 & 0 & & & & 0.91 \\
\hline & & & & & & & \\
\hline & & & & & & & 0.829 \\
\hline 3. & 0.31 & 0.686 & 0.4 & 1.2 & 0.0 & 0 & 0.856 \\
\hline 6.3 & 0.68 & 0.665 & 0.436 & 0.64 & 0.035 & 0.107 & 0.772 \\
\hline 4.3 & 0.45 & & & & 0.019 & 0.074 & \\
\hline
\end{tabular}

${ }^{a}$ From integrated area of $\mathrm{H}_{2} \mathrm{O}$ desorption above $623 \mathrm{~K}$ (Figure 4). ${ }^{b}$ Subtract value in column 3 from that for H-ZSM5 (0 wt \% Mo). ${ }^{c}$ Divide column 4 by $\mathrm{Mo} / \mathrm{Al}$ ratio. ${ }^{d}$ From $\mathrm{D}_{2}(\mathrm{~g}) / \mathrm{O}(\mathrm{s})-\mathrm{H}$ isotopic exchange (Figure 9). ${ }^{e}$ From $\mathrm{H}_{2}(\mathrm{~g}) / \mathrm{O}(\mathrm{s})-\mathrm{D}$ isotopic exchange (Figure 10). ${ }^{f}$ Sum of columns 3 and $7 .{ }^{g}$ Includes second TPO and $\mathrm{D}_{2}(\mathrm{~g}) /$ $\mathrm{O}(\mathrm{s})-\mathrm{H}$ values (see text).

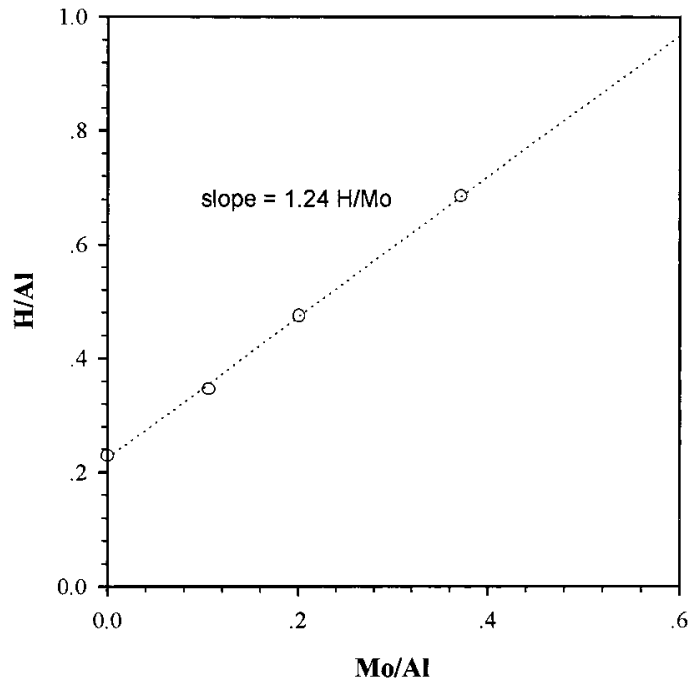

Figure 5. Number of $\mathrm{H}$ desorbed as $\mathrm{H}_{2} \mathrm{O}$ per $\mathrm{Al}$ atom during treatment of $\mathrm{MoO}_{3} / \mathrm{H}-\mathrm{ZSM} 5$ mixtures in air to $973 \mathrm{~K}$.

tion was confirmed using ${ }^{27} \mathrm{Al}$ NMR to measure the change in intensity of the peak corresponding to tetrahedral (framework) $\mathrm{Al}$ centers (as discussed later). These data show that for samples with less than 4 wt $\%$ Mo, $\mathrm{MoO}_{x}$ species exchange with $\mathrm{H}^{+}$ with a stoichiometry of about one Mo per $\mathrm{H}$ (Figure 5, slope $=$ $1.24 \mathrm{H} / \mathrm{Mo}$ ). For H-ZSM5 with a Si/Al ratio of 14.3 , the number of cation exchange sites is not sufficient to accommodate all Mo atoms in the $8 \mathrm{wt} \%$ Mo sample, and the excess $\mathrm{MoO}_{x}$ sublimes above $773 \mathrm{~K}$ during air treatment.

Vapor-Exchange Synthesis from Separated $\mathrm{MoO}_{3}$ and H-ZSM5 Powders. In a separate experiment, Mo/H-ZSM5 samples were prepared by flowing $20 \% \mathrm{O}_{2} / \mathrm{He}\left(100 \mathrm{~cm}^{3} / \mathrm{min}\right)$ over bulk $\mathrm{MoO}_{3}(0.185 \mathrm{~g})$, and contacting the $\left(\mathrm{MoO}_{3}\right)_{n}$ vapor with a bed of H-ZSM5 (1.509 g; Figure 6). The Mo content would be 7.3 wt $\%$ if all the $\mathrm{MoO}_{3}$ remained in the exchanged 


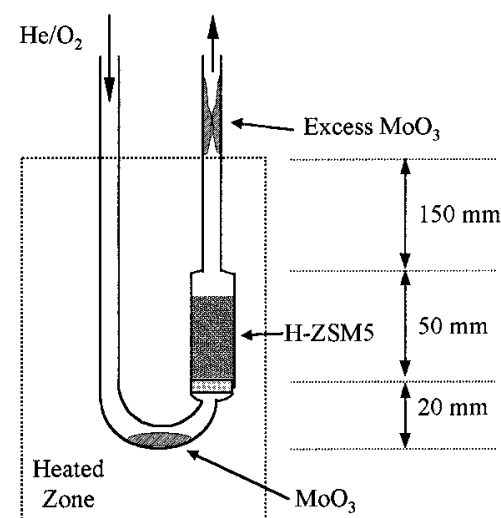

Figure 6. Preparation of "vapor-exchanged" Mo/H-ZSM5 sample (1.5 $\mathrm{g}, 50 \mathrm{~cm}^{3} / \mathrm{min}, 20 \% \mathrm{O}_{2} / \mathrm{He}, 101 \mathrm{kPa}, 950 \mathrm{~K}, 96 \mathrm{~h}$ ).

TABLE 5: $\mathrm{N}_{2}$ Physisorption at $77 \mathrm{~K}$ of $\mathrm{MoO}_{3} / \mathrm{H}-\mathrm{ZSM} 5$ Mixtures after TPO and TPR Treatment in Air and $\mathbf{H}_{2}$ $\left(D_{2}\right)$ to $973 \mathrm{~K}$

\begin{tabular}{ccc}
\hline $\begin{array}{c}\text { Mo concn } \\
(\text { wt } \%)\end{array}$ & $\begin{array}{c}\text { BET surface area } \\
\left(\mathrm{m}^{2} / \mathrm{g} \text { zeolite }\right)\end{array}$ & $\begin{array}{c}\text { micropore volume } \\
\left(\mathrm{cm}^{3} / \mathrm{g} \text { zeolite }\right)\end{array}$ \\
\hline 0 & 272 & 0.128 \\
1.1 & 278 & 0.119 \\
2.0 & 266 & 0.120 \\
3.6 & 218 & 0.107 \\
6.3 & 132 & 0.059 \\
$4.3^{a}$ & 201 & 0.084
\end{tabular}

${ }^{a}$ Prepared via $\mathrm{MoO}_{3}$ vapor exchange at $950 \mathrm{~K}, 96 \mathrm{~h}$ (see text).

samples after treatment in air. All the $\mathrm{MoO}_{3}$ powder sublimed after $96 \mathrm{~h}$ at $950 \mathrm{~K}$, contacted the H-ZSM5 sample, and either exchanged at ZSM5 sites or deposited as light green crystals (bulk $\mathrm{MoO}_{3}$ ) on colder reactor walls above the zeolite bed. The resulting Mo/H-ZSM5 contained 4.3 wt \% Mo. These results showed that surface diffusion is not required for $\mathrm{MoO}_{x}$ migration during treatment in air at high temperature $(>873 \mathrm{~K})$ and that vapor-phase transport of $\left(\mathrm{MoO}_{3}\right)_{n}$ oligomers can occur during synthesis of Mo/H-ZSM5 from physical mixtures. $\mathrm{CH}_{4}$ aromatization reaction rates were very low on this sample. At a space velocity of $750 \mathrm{~h}^{-1}, \mathrm{CH}_{4}$ conversion was only $1.7 \%$ (cf. $4.3 \mathrm{wt}$ $\%$ Mo sample; Table 1).

Zeolite Structural Changes during Thermal Treatment of $\mathrm{MoO}_{3} / \mathrm{H}-\mathrm{ZSM} 5$ Mixtures. The unusual shape of the $\mathrm{H}_{2} \mathrm{O}$ evolution rates on the 8 wt $\% \mathrm{Mo} / \mathrm{H}-\mathrm{ZSM} 5^{27}$ (Figure 4) suggested some structural differences between this sample and the others, which we explored using powder X-ray diffraction (XRD), $\mathrm{N}_{2}$ physisorption, and ${ }^{27} \mathrm{Al}$ NMR. $\mathrm{N}_{2}$ physisorption results were used to estimate surface areas and micropore volumes (Table 5). Neither diffraction nor $\mathrm{N}_{2}$ physisorption data showed any structural degradation of the zeolite in samples with 1.0 or 2.0 wt \% Mo relative to pure H-ZSM5, but both methods detected a modest loss of crystallinity in the 3.6 and $4.3 \mathrm{wt} \%$ Mo samples, and significant destruction of the zeolite framework in the $6.3 \mathrm{wt} \%$ sample. ${ }^{27} \mathrm{~A}$ loss of surface area with increasing Mo content was previously reported also for $\mathrm{MoO}_{x} / \mathrm{ZSM} 5$ prepared by AHM slurry methods. ${ }^{28}$

${ }^{27} \mathrm{Al}$ NMR spectroscopy can probe the local structure of $\mathrm{Al}$ cations in Mo/H-ZSM5 samples. Tetrahedral Al centers in the zeolite framework bonded to terminal $\mathrm{O}-\mathrm{H}$ groups have a chemical shift of $56 \mathrm{ppm}$; extraframework octahedral Al centers (in ZSM5 and in $\left.\mathrm{Al}_{2} \mathrm{O}_{3}\right)$ show no shift $(\delta=0 \mathrm{ppm})$, while crystalline $\mathrm{Al}_{2}\left(\mathrm{MoO}_{4}\right)_{3}$ (octahedral $\mathrm{Al}$, tetrahedral Mo) shows a line at -13 ppm. ${ }^{15}{ }^{27} \mathrm{Al}$ NMR spectra for $\mathrm{MoO}_{x} / \mathrm{H}-\mathrm{ZSM} 5$ samples (Figure 7) showed that the density of unperturbed framework Al centers (corresponding to Bronsted acid sites)

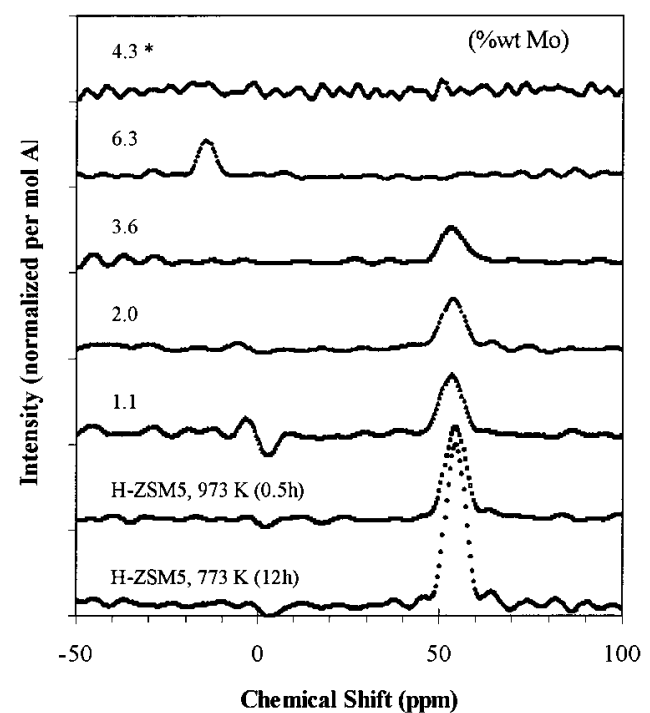

Figure 7. ${ }^{27} \mathrm{Al} \mathrm{NMR}$ spectra of $\mathrm{MoO}_{3} / \mathrm{H}-\mathrm{ZSM} 5$ physical mixtures after TPO and TPR treatments to $973 \mathrm{~K}(*) 4.3 \mathrm{wt} \%$ Mo sample prepared via $\mathrm{MoO}_{3}$ vapor exchange at $950 \mathrm{~K}, 96 \mathrm{~h}$.

decreased with increasing Mo content. ${ }^{27} \mathrm{Al}$ NMR lines corresponding to crystalline $\mathrm{Al}_{2}\left(\mathrm{MoO}_{4}\right)_{3}$ appeared in the $6.3 \mathrm{wt} \%$ $\mathrm{Mo} / \mathrm{H}-\mathrm{ZSM} 5$ sample. ${ }^{27}$ The $\mathrm{Al}_{2}\left(\mathrm{MoO}_{4}\right)_{3}$ crystallites are too small to be detected by X-ray diffraction in this sample, but they become detectable in Mo/H-ZSM5 samples with higher Mo content (15 wt \%). ${ }^{15}$

Thus, it appears that the unusual shape of the $\mathrm{H}_{2} \mathrm{O}$ desorption curve for $6.3 \mathrm{wt} \% \mathrm{Mo} / \mathrm{H}-\mathrm{ZSM} 5$ reflects the extraction of $\mathrm{Al}$ from the framework to form $\mathrm{Al}_{2}\left(\mathrm{MoO}_{4}\right)_{3}$ and the concomitant collapse of the zeolite pore structure. $\mathrm{H}_{2} \mathrm{O}$ desorption rates from mixtures initially containing 4 and 8 wt $\%$ Mo were identical up to about $850 \mathrm{~K}$ (Figure 4), indicating that $\mathrm{MoO}_{x}$-induced extraction of framework $\mathrm{Al}$ did not occur below $850 \mathrm{~K}$. This agrees with ${ }^{27} \mathrm{Al} \mathrm{NMR}$ data for 15 wt $\% \mathrm{Mo} / \mathrm{H}-\mathrm{ZSM} 5$, which showed $\mathrm{Al}_{2}\left(\mathrm{MoO}_{4}\right)_{3}$ in samples treated in air at 873 or $973 \mathrm{~K}$, but not in those treated at $773 \mathrm{~K} .{ }^{15}$ The ratio of $\mathrm{OH}$ groups removed as $\mathrm{H}_{2} \mathrm{O}$ to Mo atoms in the $6.3 \mathrm{wt} \%$ Mo sample is only 0.64 ; this value is very similar to that expected for $\mathrm{Al}_{2}$ $\left(\mathrm{MoO}_{4}\right)_{3}(0.67)$, but it is smaller than in Mo/H-ZSM5 samples with lower Mo content.

Isotopic Equilibration of $\mathrm{D}_{2}$ with $\mathrm{OH}$ Groups in $\mathrm{Mo} / \mathrm{H}$ ZSM5 Samples. The isotopic equilibration of surface $\mathrm{O}-\mathrm{H}$ groups with $\mathrm{D}_{2}$ was carried out after treating Mo/H-ZSM5 in air at $973 \mathrm{~K}$ (procedure II, Table 2). This method was used

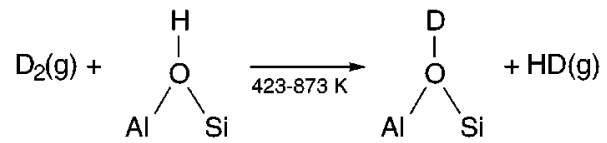

previously in order to determine the number of $\mathrm{OH}$ groups in H-ZSM5 and cation-exchanged H-ZSM5. ${ }^{16}$

$\mathrm{D}_{2} / \mathrm{O}-\mathrm{H}$ exchange data are shown in Figure 8 for 3.6 wt $\%$ Mo/H-ZSM5 (prepared by program II; Table 2). The total number of $\mathrm{H}$ atoms removed as $\mathrm{HD}$ and $\mathrm{H}_{2}$ corresponds to 0.1 $\mathrm{H}$ per $\mathrm{Al}$. Figure 9 shows $\mathrm{HD}$ desorption rates during $\mathrm{D}_{2} / \mathrm{O}-\mathrm{H}$ exchange for all samples $(0-6.3 \mathrm{wt} \% \mathrm{Mo}$; prepared by exchange in air at $973 \mathrm{~K}$ for $0.5 \mathrm{~h}$ ). The number of $\mathrm{O}-\mathrm{H}$ groups decreased with increasing Mo content, as $\mathrm{O}-\mathrm{H}$ groups were increasingly replaced by Mo during exchange (eq 1). The data in Figure 9 also show that Mo species catalyze $\mathrm{D}_{2}$ dissociation, the rate-determining step in $\mathrm{D}_{2} / \mathrm{O}-\mathrm{H}$ exchange, and thus 


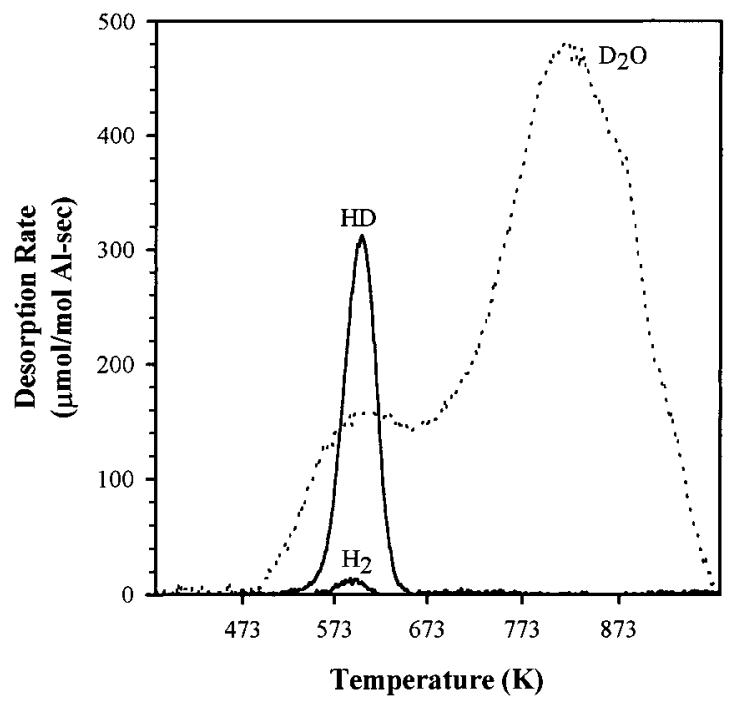

Figure 8. Production rate of $\mathrm{H}_{2}, \mathrm{HD}$, and $\mathrm{D}_{2} \mathrm{O}$ during temperatureprogrammed $\mathrm{D}_{2}(\mathrm{~g}) / \mathrm{O}-\mathrm{H}(\mathrm{s})$ isotopic exchange on $3.6 \mathrm{wt} \% \mathrm{Mo} /$ H-ZSM5 (0.3 g, $\left.100 \mathrm{~cm}^{3} / \mathrm{min} 5 \% \mathrm{D}_{2} / \mathrm{Ar}, 101 \mathrm{kPa}\right)$.

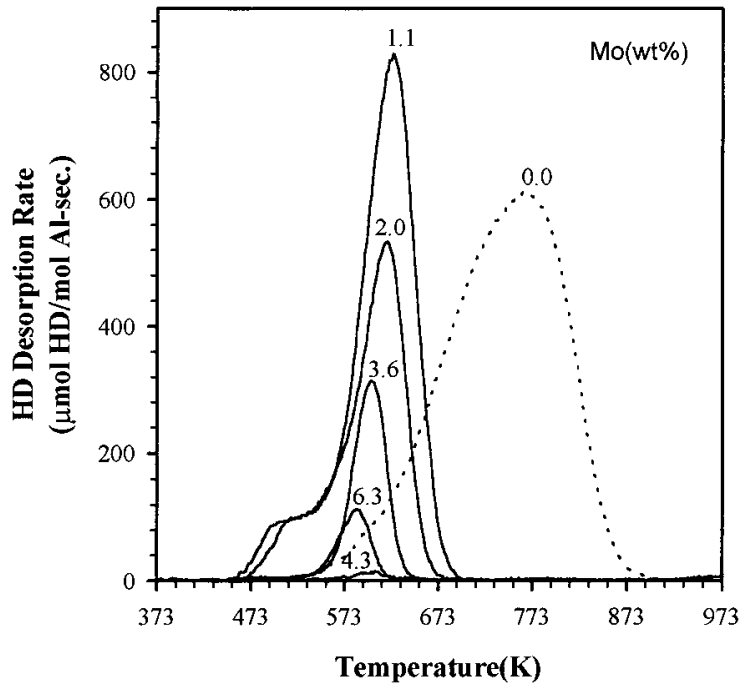

Figure 9. Rate of $\mathrm{HD}$ desorption during $\mathrm{D}_{2}(\mathrm{~g}) / \mathrm{O}-\mathrm{H}(\mathrm{s})$ isotopic exchange on Mo/H-ZSM5 $\left(0.3 \mathrm{~g}, 100 \mathrm{~cm}^{3} / \mathrm{min} 5 \% \mathrm{D}_{2} / \mathrm{Ar}, 101 \mathrm{kPa}\right)$.

decrease the temperature required for $\mathrm{D}_{2}-\mathrm{OH}$ exchange by about $200 \mathrm{~K}$.

The formation of $\mathrm{D}_{2} \mathrm{O}$ during $\mathrm{D}_{2} / \mathrm{O}-\mathrm{H}$ exchange above 500 $\mathrm{K}$ (Figure 8) reflects some reduction of $\mathrm{Mo}^{6+}$ species. This process influences the calculated exchange values, because both $\mathrm{H}_{2} \mathrm{O}$ and $\mathrm{HDO}$ form via $\mathrm{D}_{2} \mathrm{O}$ exchange with $\mathrm{OH}$ groups. $\mathrm{H}_{2} \mathrm{O}$ and $\mathrm{HDO}$ contain $\mathrm{H}$ atoms from surface $\mathrm{O}-\mathrm{H}$ groups, but their concentrations and isotopic contents are difficult to measure because of water adsorption and exchange on the heated walls of the cell and the transfer lines. These effects were shown to be small by cooling the samples to $300 \mathrm{~K}$ after $\mathrm{D}_{2}(\mathrm{~g}) / \mathrm{O}(\mathrm{s})-\mathrm{H}$ exchange, and then heating to $973 \mathrm{~K}$ in flowing $\mathrm{H}_{2}$; the measured amounts of $\mathrm{HD}$ and $\mathrm{D}_{2}$ formed (Figure 10, denoted as $\mathrm{H}_{2}(\mathrm{~g}) / \mathrm{O}(\mathrm{s})-\mathrm{D}$ exchange) gave densities of residual $\mathrm{OD}$ groups that were only slightly different from those measured from the initial $\mathrm{D}_{2}-\mathrm{OH}$ exchange.

$\mathrm{D}_{2} / \mathrm{O}-\mathrm{H}$ and $\mathrm{H}_{2} / \mathrm{O}-\mathrm{D}$ exchange data show that each $\mathrm{Mo}$ added to H-ZSM5 replaces $1.0 \pm 0.2 \mathrm{OH}$ groups during exchange from physical mixtures at $973 \mathrm{~K}$ (Figure 11). ${ }^{29}$ Tetrahedral $\mathrm{Al}$ atoms containing an $\mathrm{OH}$ group $\left(\mathrm{Al}_{\mathrm{F}}\right)$ give a ${ }^{27} \mathrm{Al}$ NMR line that decreases in intensity as Mo content increases. These data allow us to calculate the fraction of the $\mathrm{Al}$ centers

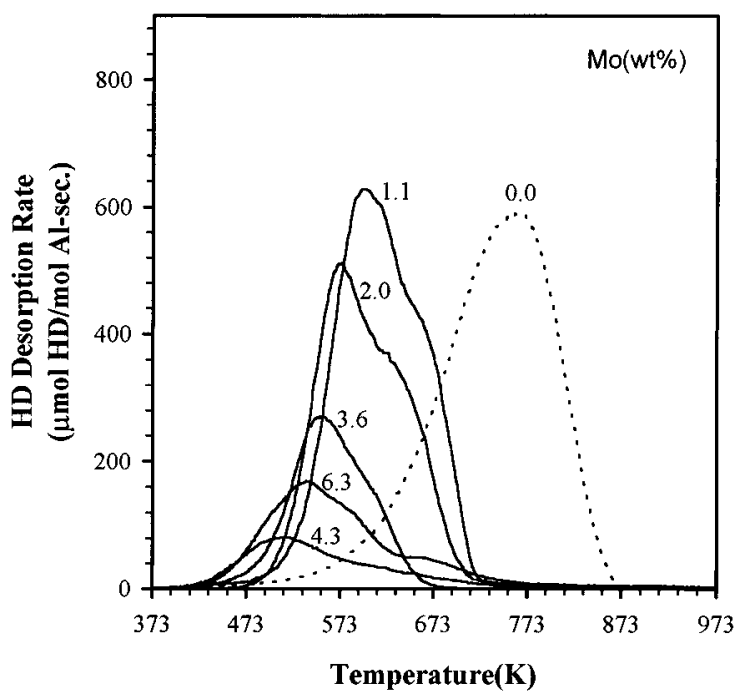

Figure 10. Rate of HD desorption during $\mathrm{H}_{2}(\mathrm{~g}) / \mathrm{O}-\mathrm{D}(\mathrm{s})$ isotopic exchange on Mo/H-ZSM5 (0.3 g, $\left.100 \mathrm{~cm}^{3} / \mathrm{min} 5 \% \mathrm{D}_{2} / \mathrm{Ar}, 101 \mathrm{kPa}\right)$.

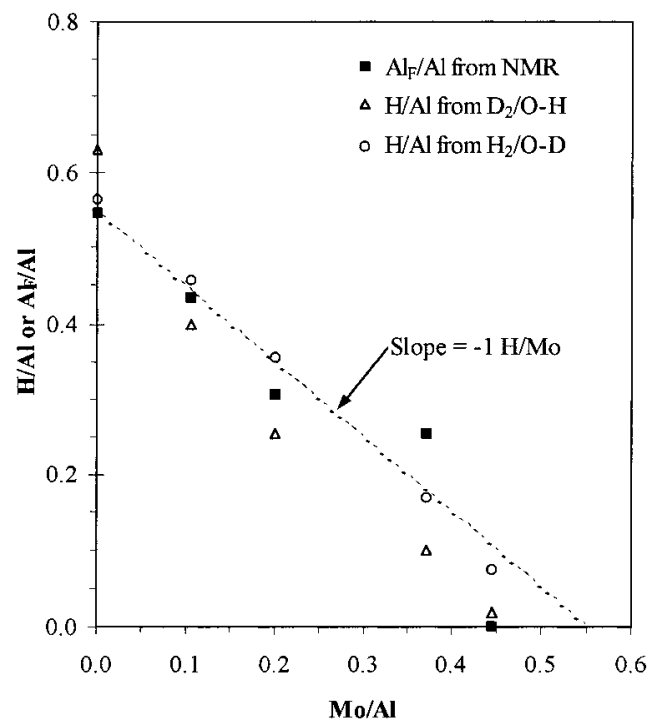

Figure 11. Number of acid sites $(\mathrm{H})$ or framework $\mathrm{Al}\left(\mathrm{Al}_{\mathrm{F}}\right)$ remaining per total $\mathrm{Al}$ for series of Mo/H-ZSM5 samples after TPO and TPR treatment to $973 \mathrm{~K}(0.5 \mathrm{~h})$ measured by ${ }^{27} \mathrm{Al} \mathrm{NMR}, \mathrm{D}_{2} / \mathrm{O}-\mathrm{H}$, and $\mathrm{H}_{2} /$ $\mathrm{O}-\mathrm{D}\left(0.45 \mathrm{Mo} / \mathrm{Al}\right.$ sample prepared via $\mathrm{MoO}_{3}$ vapor exchange at 950 $\mathrm{K}, 96 \mathrm{~h})$.

that interact with $\mathrm{MoO}_{x}$ species instead of $\mathrm{OH}$ groups (Figure 7), using a value of 0.92 for the $\mathrm{Al}_{\mathrm{F}} / \mathrm{Al}$ ratio in a H-ZSM5 sample pretreated in air at $773 \mathrm{~K}$ for $1 \mathrm{~h}$ (Table 4). ${ }^{30}$ The results from $\mathrm{D}_{2}-\mathrm{OH}, \mathrm{H}_{2}-\mathrm{OD}$, and ${ }^{27} \mathrm{Al} \mathrm{NMR}$ are in excellent agreement (Figure 11); they show that each Mo replaces one $\mathrm{OH}$ group, as expected for $\left(\mathrm{Mo}_{2} \mathrm{O}_{5}\right)^{2+}$ dimers bridging two cation exchange sites.

The sum of the $\mathrm{OH}$ groups removed as $\mathrm{H}_{2} \mathrm{O}$ during exchange and those remaining (from $\mathrm{D}_{2} / \mathrm{O}-\mathrm{H}$ data) should correspond to the total number of $\mathrm{OH}$ groups in the starting H-ZSM5 samples (Table 4). On H-ZSM5, the two TPO experiments and the $\mathrm{D}_{2}-\mathrm{OH}$ exchange add to a value of $0.92 \mathrm{OH} / \mathrm{Al}$ (Table 4)..$^{30}$ All Mo samples had values of $0.77-0.86$ total $\mathrm{OH} / \mathrm{Al}$, in reasonable agreement with the value of 0.92 measured on H-ZSM5 (Table 4).

\section{Discussion}

X-ray diffraction, $\mathrm{N}_{2}$ physisorption, and ${ }^{27} \mathrm{Al}$ NMR methods show that after treatment in air at $973 \mathrm{~K}, \mathrm{MoO}_{x} / \mathrm{H}-\mathrm{ZSM} 5$ 


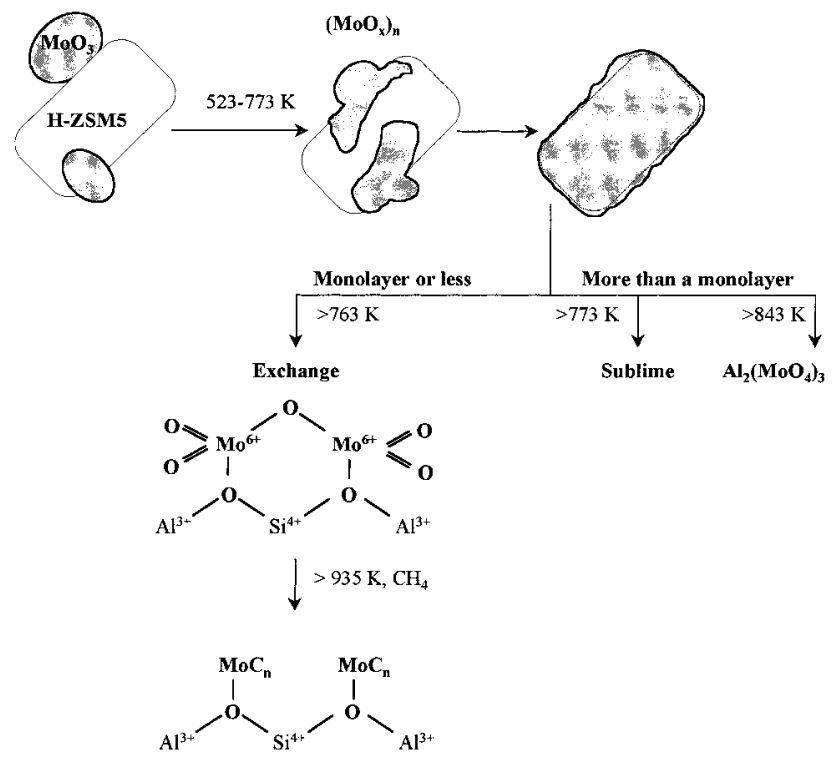

Figure 12. Formation of Mo/H-ZSM5 active sites from $\mathrm{MoO}_{3} / \mathrm{H}-\mathrm{ZSM} 5$ physical mixtures.

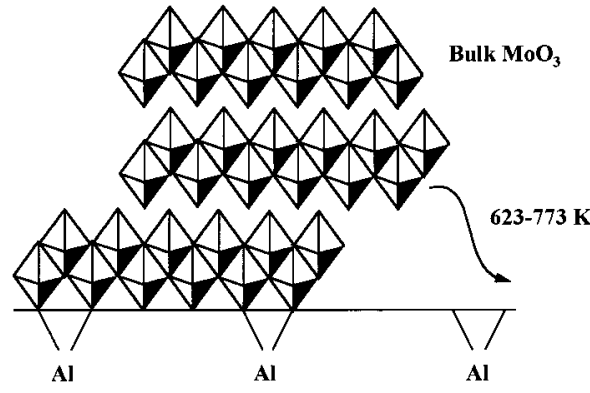

H-ZSM5 external surface

Figure 13. Structure of bulk $\mathrm{MoO}_{3}$ and solid-state migration on H-ZSM5 surface.

samples prepared from $\mathrm{MoO}_{3}-\mathrm{H}-\mathrm{ZSM} 5$ physical mixtures lead to exchanged Mo species similar to those obtained from aqueous exchange methods. Low $\mathrm{pH}$ conditions may alter the density and nature of external $\mathrm{OH}$ groups on zeolite crystals, ${ }^{31}$ which can lead to $\mathrm{MoO}_{x}$ binding and may account for the high external Mo concentrations detected by X-ray photoelectron spectroscopy on samples prepared by aqueous exchange. ${ }^{26,31}$ Methane conversion rates and selectivities are similar on samples prepared by the two methods, suggesting that active site densities and aromatization pathways are similar in $\mathrm{MoO}_{x} / \mathrm{H}$-ZSM5 samples prepared from physical mixtures (this study) and in those prepared using aqueous exchange. 1,3,6,28,32,33

Migration of $\mathrm{MoO}_{x}$ Species during Treatment in Air. Our results are consistent with the processes depicted schematically in Figure 12. Below $623 \mathrm{~K}$, X-ray diffraction shows that $\mathrm{MoO}_{3}$ and $\mathrm{H}-\mathrm{ZSM} 5$ crystallites remain intact. Between $623 \mathrm{~K}$ and 773 $\mathrm{K}, \mathrm{MoO}_{3}$ crystallites disappear as $\mathrm{MoO}_{x}$ migrates onto external zeolite surfaces. Knözinger, et al. ${ }^{34}$ have proposed that $\mathrm{MoO}_{3}$ spreads on $\mathrm{Al}_{2} \mathrm{O}_{3}$ surfaces via an "unrolling carpet" mechanism. Above $600 \mathrm{~K}, \mathrm{MoO}_{3}$ layers migrate until they reach $\mathrm{AlO}_{x}$ sites, where they anchor and become immobile (Figure 13). This process decreases surface energies as $\mathrm{MoO}_{3}$ forms strong bonds with $\mathrm{Al}_{2} \mathrm{O}_{3}$; similar processes were not detected on $\mathrm{SiO}_{2} .{ }^{35}$ These data and the stability of $\mathrm{Al}_{2}\left(\mathrm{MoO}_{4}\right)_{3}$ suggest that $\mathrm{Al}-\mathrm{O}-\mathrm{Mo}$ bonds are stronger than $\mathrm{Si}-\mathrm{O}-\mathrm{Mo}$ bonds. ${ }^{36}$

$\mathrm{MoO}_{3}$ consists of $\mathrm{MoO}_{6}$ octahedra with displaced central Mo atoms. ${ }^{37} \mathrm{MoO}_{6}$ octahedra form bilayers with van der Waals interlayer binding (Figure 13). Between 623 and $773 \mathrm{~K}$,

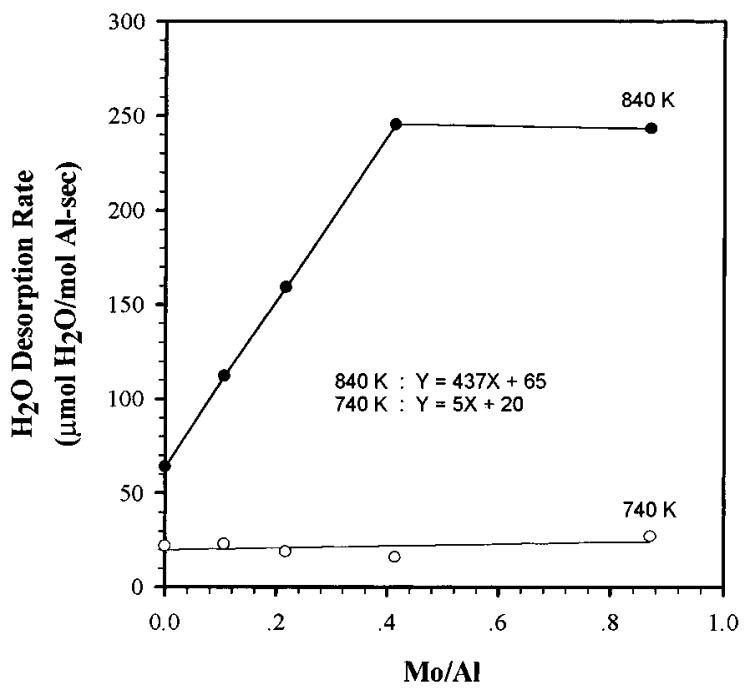

Figure 14. $\mathrm{H}_{2} \mathrm{O}$ desorption rate during TPO of $\mathrm{MoO}_{3} / \mathrm{H}-\mathrm{ZSM} 5$ mixtures at 740 and $840 \mathrm{~K}$ (from Figure 4). (*) Mo/Al ratios are as prepared. Mo concentrations after TPO are shown in Table 3.

vibrations overcome this binding and bilayers slide over each other until they anchor at Al sites on external ZSM5 surfaces. ${ }^{38}$ $\mathrm{MoO}_{x}$ species may also migrate into zeolite channels at these temperatures, but they do not react with $\mathrm{O}-\mathrm{H}$ groups, as shown by the low rate of $\mathrm{H}_{2} \mathrm{O}$ formation below $\sim 750 \mathrm{~K}$ and by the lack of dependence of this rate on the Mo content (Figure 14).

After the external ZSM5 surface is covered completely with a $\mathrm{MoO}_{3}$ layer above $773 \mathrm{~K}$, further spreading cannot decrease the surface energy. In our study, samples with more than $4 \mathrm{wt}$ $\%$ Mo contain more Mo than that required to form a $\mathrm{MoO}_{3}$ monolayer on the external surface area of the ZSM5 crystals used. The excess $\mathrm{MoO}_{x}$ can sublime as $\left(\mathrm{MoO}_{3}\right)_{n}$, as expected from the $\mathrm{MoO}_{3}$ vapor pressure and from the observed loss of Mo in samples with high Mo content (Table 3). Excess Mo can also migrate into ZSM5 channels as isolated $\mathrm{MoO}_{x}$ species (as shown by the disappearance of XRD peaks and by the observed increase of $\mathrm{H}_{2} \mathrm{O}$ desorption rate above $773 \mathrm{~K}$; Figure 14) or extract $\mathrm{Al}$ from the ZSM5 framework to form $\mathrm{Al}_{2}\left(\mathrm{MoO}_{4}\right)_{3}$ (detected in the 8 wt \% Mo sample by ${ }^{27} \mathrm{Al} \mathrm{NMR}$ and confirmed by the unusual shape of the $\mathrm{H}_{2} \mathrm{O}$ desorption curve for this sample above $850 \mathrm{~K}$; Figure 4).

The strong $\mathrm{Al}-\mathrm{O}-\mathrm{Mo}$ interactions that lead to the spreading of $\mathrm{MoO}_{3}$ on external zeolite surfaces also prevent $\mathrm{MoO}_{3}$ sublimation. Thus, physical mixtures with less Mo than that required to form a single $\mathrm{MoO}_{3}$ layer $(1-2 \mathrm{wt} \% \mathrm{Mo})$ do not lose Mo by sublimation. The mixture containing 4 wt \% Mo required treatment in air at $773 \mathrm{~K}$ for $24 \mathrm{~h}$ in order to attain full spreading of a $\mathrm{MoO}_{x}$ layer and to avoid sublimation during exchange (Table 2, program III). Even after this treatment, the 8 wt $\% \mathrm{Mo} / \mathrm{H}-\mathrm{ZSM} 5$ sample lost about $20 \%$ of its $\mathrm{MoO}_{3}$ by sublimation (Table 3). This shows that the maximum $\mathrm{MoO}_{3}$ coverage for the external (mesoporous) surface area of the ZSM5 used $\left(24 \mathrm{~m}^{2} / \mathrm{g}\right)$ corresponds to about 4 wt $\% \mathrm{Mo}^{39}$

$\mathrm{H}_{2} \mathrm{O}$ evolution rates (per $\mathrm{Al}$ or g-catalyst) during air treatment of $\mathrm{MoO}_{3} / \mathrm{H}-\mathrm{ZSM} 5$ mixtures at high temperatures (Figure 4) reflect the rate of replacement of $\mathrm{H}^{+}$with cationic Mo oxo species. This rate of exchange in turn depends on the mobility of migrating Mo species and on the number of ZSM5 channels available for transport. Below $740 \mathrm{~K}, \mathrm{H}_{2} \mathrm{O}$ evolution rates are independent of Mo content (Figure 14), indicating that $\mathrm{MoO}_{x}$ species do not undergo the condensation reactions that anchor them at exchange sites. Between 750 and $850 \mathrm{~K}, \mathrm{H}_{2} \mathrm{O}$ evolution rates become proportional to the Mo content for samples with 


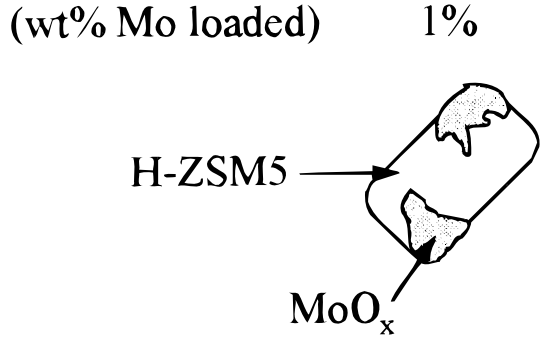

$1.0-3.6$ wt $\% \mathrm{Mo}(\mathrm{Mo} / \mathrm{Al}=0.11-0.37$; Figure 14$)$. These data suggest that zeolite channels become accessible to the external $\mathrm{MoO}_{3}$ surface layer in proportion to the amount of Mo spread as a layer on the external zeolite surface (at least up to $3.6 \mathrm{wt}$ $\% \mathrm{Mo}$ ). At higher Mo contents, $\mathrm{H}_{2} \mathrm{O}$ desorption rates remain constant as temperatures increase from 750 and $850 \mathrm{~K}$, suggesting that the external $\mathrm{MoO}_{3}$ exceeds one monolayer and that all channel openings become accessible to $\mathrm{MoO}_{3}$; then, condensation reactions become limited by rate of Mo migration within ZSM5 channels. These data are consistent with the scheme in eq 5 and with expected formation of a single $\mathrm{MoO}_{3}$ layer in the $3.6 \mathrm{wt} \%$ Mo samples for the external area available in the H-ZSM5 crystals used in the physical mixtures.

On the sample with the highest Mo content ( $7.9 \mathrm{wt} \%$ Mo in mixture; 6.3 wt $\%$ after exchange), multiple $\mathrm{MoO}_{3}$ layers can form on external zeolite surfaces. Above $843 \mathrm{~K}, \mathrm{AlO}_{x}$ species can be extracted from the aluminosilicate and dissolved into liquidlike $\mathrm{MoO}_{3}$ layers, within which they can react to form stable $\mathrm{Al}_{2}\left(\mathrm{MoO}_{4}\right)_{3}$ domains. $\mathrm{Al}_{2}\left(\mathrm{MoO}_{4}\right)_{3}$ was detected by ${ }^{27} \mathrm{Al}$ NMR and X-ray diffraction ${ }^{15}$ in samples with high Mo content. In our study, $\mathrm{Al}_{2}\left(\mathrm{MoO}_{4}\right)_{3}$ was not detected in samples with less than 4 wt $\%$ Mo, because $\mathrm{MoO}_{3}$ monolayers apparently lack the local three-dimensional structure and the thermodynamic incentive required to stabilize $\mathrm{Al}$ in $\mathrm{Al}_{2}\left(\mathrm{MoO}_{4}\right)_{3}$ structures.

The extraction of $\mathrm{AlO}_{x}$ species from the aluminosilicate framework to form $\mathrm{Al}_{2}\left(\mathrm{MoO}_{4}\right)_{3}$ causes the structural collapse detected by $\mathrm{X}$-ray diffraction and $\mathrm{N}_{2}$ physisorption measurements in the Mo/H-ZSM5 sample with 6.3 wt \% Mo. ${ }^{27}$ High temperatures alone do not cause the observed structural collapse, because "vapor-exchanged" (4.3 wt \% Mo) samples were treated at $950 \mathrm{~K}$ for $96 \mathrm{~h}$ without significant loss of crystallinity and ${ }^{27} \mathrm{Al} \mathrm{NMR}$ did not detect any $\mathrm{Al}_{2}\left(\mathrm{MoO}_{4}\right)_{3}$. It appears that high local $\mathrm{MoO}_{x}$ concentrations are required in order to extract $\mathrm{Al}$ from the aluminosilicate framework. The sample with $6.3 \mathrm{wt}$ $\%$ Mo (7.9 wt \% Mo in starting mixture) and the vaporexchanged sample were exposed to similar $\mathrm{MoO}_{x}$ concentrations (7.9 wt \% vs 7.3 wt \% Mo), but vapor-exchanged samples were contacted by $\left(\mathrm{MoO}_{3}\right)_{n}(n \sim 3-4)$ oligomers at a pressure of about $25 \mathrm{~Pa}(250 \mathrm{ppm}),{ }^{11}$ while the 8 wt \% Mo sample contained significant interfacial area between liquidlike bulk $\mathrm{MoO}_{3}$ and zeolite surfaces. Thus, local $\mathrm{MoO}_{3}$ concentrations are lower during vapor exchange synthesis (Figure 6), because $\left(\mathrm{MoO}_{3}\right)_{n}$ oligomers adsorb onto the ZSM5 surface, migrate within zeolite channels, and bind irreversibly at sites where they form Mo$\mathrm{O}-\mathrm{Al}$ bonds before high local $\mathrm{MoO}_{3}$ concentrations are reached.

Exchange of Cationic Mo Oxo Species via Condensation Reactions. The amount of water evolved during exchange and the number of $\mathrm{O}-\mathrm{H}$ groups remaining after exchange show that each migrating $\mathrm{MoO}_{x}$ replaces one $\mathrm{H}^{+}$in $\mathrm{H}-\mathrm{ZSM}$ (Figures 5 and 11). These data and the required charge balance suggest that $\left(\mathrm{Mo}_{2} \mathrm{O}_{5}\right)^{2+}$ dimers interacting with two exchange sites form during exchange (eq 1), which acquire the ditetrahedral structure of $\left(\mathrm{Mo}_{2} \mathrm{O}_{7}\right)^{2-}$ dimers when two framework oxygen atoms provide the anchoring sites for such dimers. Infrared bands
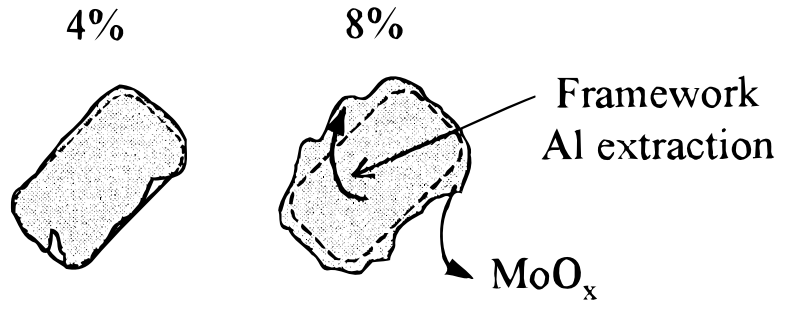

\section{sublimation}

corresponding to tetrahedral $\mathrm{Mo}^{6+}$ centers were detected previously but incorrectly assigned to $\left(\mathrm{MoO}_{4}\right)^{2-}$ monomers bridging two exchange sites, ${ }^{6}$ a stoichiometry that is not consistent with our results. The size of $\left(\mathrm{Mo}_{2} \mathrm{O}_{7}\right)^{2-}$ ditetrahedra in tetra- $n$ butylammonium dimolybdate $(\sim 5.7 \AA)^{40}$ and simple geometrical considerations based on a ZSM5 crystal structure with randomly distributed $\mathrm{Al}$ ions showed that about $60 \%$ of the $\mathrm{Al}$ atoms in H-ZSM5 $(\mathrm{Si} / \mathrm{Al}=14)$ can reside sufficiently close to another Al to allow Mo dimers to bridge Al pairs. ${ }^{41}$ The exclusive presence of $\left(\mathrm{Mo}_{2} \mathrm{O}_{5}\right)^{2+}$ dimers is then possible at all $\mathrm{Mo} / \mathrm{Al}$ ratios below 0.6 (i.e., $<5 \mathrm{wt} \%$ Mo for our $\mathrm{Si} / \mathrm{Al}$ zeolite ratio).

${ }^{27} \mathrm{Al} \mathrm{NMR}$ shows that all $\mathrm{Al}$ centers in vapor-exchanged Mo/ H-ZSM5 have been displaced from framework crystallographic positions (Figure 7). Thus, either $\mathrm{Al}$ centers are interacting with $\left(\mathrm{Mo}_{2} \mathrm{O}_{5}\right)^{2+}$ dimers or they have been extracted from the framework via condensation of two $\mathrm{O}-\mathrm{H}$ groups at next nearest neighbor $\mathrm{Al}$ atoms. All $\mathrm{Al}-\mathrm{OH}$ species in $\mathrm{H}-\mathrm{ZSM} 5$ ultimately find the next nearest neighbor required to anchor a Mo dimer or to dehydrate during the extended treatment in air $(96 \mathrm{~h}$ at $950 \mathrm{~K})$ required for vapor-phase exchange. The apparent high density of $\mathrm{Al}$ site pairs in this sample may reflect the migration of $\mathrm{Al}$ centers by exchange with $\mathrm{Si}$ atoms above $773 \mathrm{~K},{ }^{42}$ a process that stops when thermodynamically stable $\mathrm{Al}-\mathrm{O}-\mathrm{Al}$ or $\mathrm{Mo}-\mathrm{O}-\mathrm{Al}$ bonds form via condensation reactions. The required migration can occur via "hopping" into lattice vacancies or defects, via thermally-induced exchange of $\mathrm{Si}$ with $\mathrm{Al}$, or by $\mathrm{H}_{2} \mathrm{O}$-assisted diffusion pathways. When $\mathrm{Al}$ atoms reside momentarily near another one (as a next nearest neighbor or across a channel), their $\mathrm{OH}$ groups react to form $\mathrm{H}_{2} \mathrm{O}$ and an $\mathrm{O}^{2-}$ vacancy, or exchange with two $\left(\mathrm{MoO}_{2} \mathrm{OH}\right)^{+}$, which can then condense to form a $\left(\mathrm{Mo}_{2} \mathrm{O}_{5}\right)^{2+}$ dimer containing a bridging oxygen atom. Either event stabilizes $\mathrm{Al}-\mathrm{O}-\mathrm{Al}$ or $\mathrm{Al}-\mathrm{O}-\mathrm{Mo}$ site pairs slightly detached from framework positions, distorted from tetrahedral symmetry, and invisible by ${ }^{27} \mathrm{Al} \mathrm{NMR}$.

${ }^{27} \mathrm{Al} \mathrm{NMR}$ data (Figure 7) confirmed the nature of the exchanged Mo species and the details of the migration and exchange processes. The intensity of the line at $56 \mathrm{ppm}$, corresponding to tetrahedral Al center in the ZSM5 framework, decreased as the Mo content increased for samples with less than $4 \mathrm{wt} \% \mathrm{Mo}$; this decrease in intensity was not compensated by the detection of new or more intense NMR lines. At higher Mo contents, the framework $\mathrm{Al}$ line was not detected, but strong lines corresponding to $\mathrm{Al}_{2}\left(\mathrm{MoO}_{4}\right)_{3}$ appear. No NMR lines were detected $(\delta=-416$ and $543 \mathrm{ppm})$ in vapor-exchanged $(4.3 \mathrm{wt}$ $\%) \mathrm{Mo} / \mathrm{H}-\mathrm{ZSM} 5$ samples. This shows that vapor exchange creates neither $\mathrm{Al}_{2} \mathrm{O}_{3}$ nor $\mathrm{Al}_{2}\left(\mathrm{MoO}_{4}\right)_{3}$ in samples with this $\mathrm{Mo}$ content. The anchoring of $\left(\mathrm{Mo}_{2} \mathrm{O}_{5}\right)^{2+}$ dimers appears to form $\mathrm{Mo}-\mathrm{O}-\mathrm{Al}$ bonds that distort the tetrahedral structure of framework $\mathrm{Al}$ centers, leading to the typical broadening of lines for quadrupolar Al nuclei with decreasing symmetry. ${ }^{43}$ The $\mathrm{Al}$ symmetry at exchange sites bonded to $\left(\mathrm{Mo}_{2} \mathrm{O}_{5}\right)^{2+}$ dimers differs markedly from that observed in known $\mathrm{Al}$ compounds. $\mathrm{Al}^{3+}$ centers have tetrahedral coordination in aluminosilicate frameworks and octahedral symmetry in $\gamma-\mathrm{Al}_{2} \mathrm{O}_{3} . \mathrm{Al}_{2}\left(\mathrm{MoO}_{4}\right)_{3}$ has 


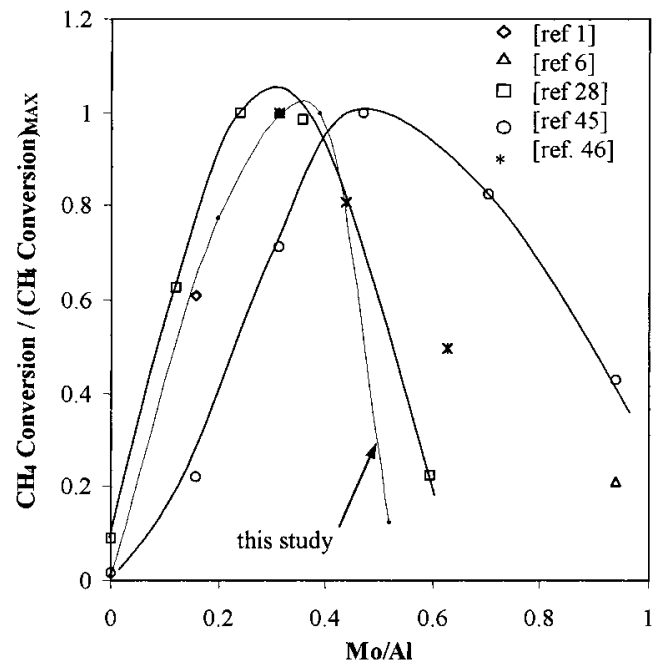

Figure 15. Literature reports of $\mathrm{CH}_{4}$ conversion, normalized by the maximum conversion reported in each study, as a function of $\mathrm{Mo} / \mathrm{Al}$ ratio. The solid lines connect data from a single study.

octahedral $\mathrm{Al}$ centers and tetrahedral Mo centers, while $\left(\mathrm{Mo}_{2} \mathrm{O}_{5}\right)^{2+}$ dimers located at two cation exchange sites would have distorted tetrahedral $\mathrm{Al}$ centers bound to distorted tetrahedral $\mathrm{Mo}^{6+}$; it is this required distortion that leads to the broadening of NMR lines after exchange or dehydroxylation of zeolites.

Formation of Active Sites during $\mathbf{C H}_{\mathbf{4}}$ Aromatization. The predominant formation of $\mathrm{CO}_{x}, \mathrm{H}_{2} \mathrm{O}$, and $\mathrm{H}_{2}$ during initial contact of $\mathrm{MoO}_{x} / \mathrm{H}-\mathrm{ZSM} 5$ with $\mathrm{CH}_{4}$ at $950 \mathrm{~K}$ (Figure 1) and the increase in hydrocarbon formation rates with increasing time on stream suggest that active sites are created by the reduction and carburization of $\left(\mathrm{Mo}_{2} \mathrm{O}_{5}\right)^{2+}$ species that are not active for methane conversion to hydrocarbons. Sites in $\left(\mathrm{Mo}_{2} \mathrm{O}_{5}\right)^{2+}$ dimers react with $\mathrm{C}-\mathrm{H}$ bonds in $\mathrm{CH}_{4}$, but they cannot desorb the resulting fragments, which form instead $\mathrm{MoC}_{x}$ species via subsequent dehydrogenation steps. Catalytic $\mathrm{CH}_{4}$ activation begins only after reduced Mo species are passivated by the formation of these carbide species, which are then able to desorb reaction products and complete a turnover. The high melting point and the low volatility of Mo suboxides and carbides ${ }^{11}$ suggest that migration is unlikely to occur after reductioncarburization of exchanged $\left(\mathrm{Mo}_{2} \mathrm{O}_{5}\right)^{2+}$. These conclusions are consistent with detailed characterization studies reported elsewhere. ${ }^{44,47}$

Exchanged $\left(\mathrm{Mo}_{2} \mathrm{O}_{5}\right)^{2+}$ species are precursors to $\mathrm{CH}_{4}$ activation sites in Mo/H-ZSM5 catalysts. Therefore, $\mathrm{CH}_{4}$ conversion rates increase with increasing extent of Mo exchange during synthesis. Reaction pathways, however, also require Bronsted acid sites, provided by the remaining $\mathrm{H}^{+}$species in ZSM5. These acid sites catalyze chain growth and cyclization reactions of the initial ethylene products formed in $\mathrm{CH}_{4}$ activation steps; thus, acid sites shift the product distributions toward aromatics, which are favored over alkenes by thermodynamics. As a result, the fraction of the $\mathrm{Al}$ sites exchanged by $\mathrm{Mo}(\mathrm{Mo} / \mathrm{Al})$, and not the Mo content, becomes the relevant parameter determining catalytic rates. Our H-ZSM5 samples $(\mathrm{Si} / \mathrm{Al}=14.3)$ lose about $40 \%$ of the framework $\mathrm{Al}$ sites during air treatment at $973 \mathrm{~K}$; for these samples, the optimum Mo concentration for $\mathrm{CH}_{4}$ aromatization is about $0.4 \mathrm{Mo} / \mathrm{Al}$ (Figure 15 ) or about $0.7 \mathrm{Mo} /$ $\mathrm{Al}_{\mathrm{F}}$ if only framework $\mathrm{Al}$ are assumed to stabilize $\mathrm{H}^{+}$. In these samples, the remaining Bronsted acid sites are sufficient to catalyze $\mathrm{C}_{2} \mathrm{H}_{4}$ aromatization reactions to near-equilibrium levels. Figure 15 shows our data and those from previous studies, ${ }^{1,6,28,45,46}$ as $\mathrm{CH}_{4}$ reaction rates vs $\mathrm{Mo} / \mathrm{Al}$ ratio. All studies detect maximum relative rates on catalysts with $0.3-0.5 \mathrm{Mo} /$
$\mathrm{Al}$ ratios, even though the zeolite $\mathrm{Si} / \mathrm{Al}$ ratio varied over a wide range (12.5-50) in these samples.

\section{Conclusion}

$\mathrm{CH}_{4}$ conversion rates on catalysts prepared from mixtures of $\mathrm{MoO}_{3}$ and $\mathrm{H}$-ZSM5 powders are very similar to those obtained on samples prepared via aqueous impregnation-exchange methods. The simpler synthesis from physical mixtures allows measurements of the kinetics of formation and of the stoichiometry of exchanged $\mathrm{MoO}_{x}$ species. $\mathrm{H}_{2} \mathrm{O}$ evolved during heating reflects the kinetics of condensation pathways that anchor $\mathrm{MoO}_{x}$ at zeolite exchange sites. Isotopic equilibration between $\mathrm{D}_{2}$ and residual $\mathrm{OH}$ groups after exchange gives the fraction of $\mathrm{H}^{+}$ species replaced by exchanged Mo oxo cations. The mechanism of exchange involves the initial formation of an external $\mathrm{MoO}_{3}$ monolayer on zeolite crystals via surface migration at 623$773 \mathrm{~K}$. When the Mo content exceeds that required to form a monolayer ( $\sim-5$ wt $\%$ Mo in the H-ZSM5 used), $\mathrm{MoO}_{x}$ species are lost as $\left(\mathrm{MoO}_{3}\right)_{n}$ oligomers via sublimation or as unreducible and inactive $\mathrm{Al}_{2}\left(\mathrm{MoO}_{4}\right)_{3}$ domains via reactions with framework $\mathrm{Al}$ atoms. Between 773 and $973 \mathrm{~K}$, surface and gasphase transport paths lead to migration of $\mathrm{MoO}_{x}$ species into zeolite channels and to reactions with $\mathrm{OH}$ groups to form $\mathrm{MoO}_{2^{-}}$ $(\mathrm{OH})^{+}$species that condense quickly to form $\mathrm{H}_{2} \mathrm{O}$ and a strong $\mathrm{Mo}-\mathrm{O}-\mathrm{Al}$ anchoring bond. The amount of $\mathrm{H}_{2} \mathrm{O}$ evolved during exchange and the number of $\mathrm{H}^{+}$remaining after exchange are consistent with the replacement of one $\mathrm{H}^{+}$by each exchanged Mo. This stoichiometry and the requirement for charge neutrality during exchange lead to the proposal that Mo species exist as $\left(\mathrm{Mo}_{2} \mathrm{O}_{5}\right)^{2+}$ ditetrahedra interacting with two zeolite exchange sites. These $\left(\mathrm{Mo}_{2} \mathrm{O}_{5}\right)^{2+}$ dimers reduce and carburize during methane reactions to form the active $\mathrm{MoC}_{x}$ sites required for catalytic $\mathrm{C}-\mathrm{H}$ bond activation. Maximum rates are observed on catalysts with intermediate $\mathrm{Mo} / \mathrm{Al}$ ratios $(\sim 0.4)$, because both exchanged cations and residual Bronsted acid sites are required for the conversion of methane to $\mathrm{C}_{6}+$ aromatics.

Acknowledgment. R.B. was supported by a National Science Foundation Fellowship. Y.-H.K. was supported by the Korean Science and Engineering Foundation (KOSEF). The project was funded by the Federal Energy Technology Center of the U.S. Department of Energy (DE-AC03-76SF00098) under the technical supervision of Dr. Daniel Driscoll.

\section{References and Notes}

(1) Wang, L.; Tao, L.; Xie, M.; Xu, G. Catal. Lett. 1993, 21, 35.

(2) Solymosi, F.; Erdohelyi, A.; Szoke, A. Catal. Lett. 1995, 32, 43. 289.

(3) Wang, D.; Lunsford, J. H.; Rosynek, M. P. Top. Catal. 1996, 3,

(4) Liu, S.; Dong, Q.; Ohnishi, R.; Ichikawa, M. J. Chem. Soc., Chem. Commun. 1997, 1455.

(5) Stakheev, A. Y.; Khodakov, A. Y.; Kustov, L. M.; Kazansky, V. B.; Minachev, Kh. M. Zeolites 1992, 12, 866. 233.

(6) Xu, Y.; Shu, Y.; Liu, S.; Huang, J.; Guo, X. Catal. Lett. 1995, 35,

(7) Dong, Y.; Liu, S.; Zhang, Q.; Liu, J.; Yang, K. Acta Pet. Sin. (Pet. Process. Sect.) 1992, 8, 66.

(8) Xu, Y.; Liu, S.; Wang, L.; Xie, M.; Guo, X. Catal. Lett. 1995, $135,135$.

(9) Satterfield, C. N. Heterogeneous Catalysis in Industrial Practice, 2nd ed.; McGraw-Hill, Inc.: New York, 1991.

(10) Brewer, L. Molybdenum: Physico-chemical properties of its compounds and alloys; International Atomic Energy Agency: Vienna, 1980; Vol. 7.

(11) Knacke, O., Kubaschewski, O., Hesselmann, K., Eds. Thermochemical Properties of Inorganic Substances II, 2nd ed.,; Springer-Verlag: Berlin, 1991; Vol. 2.

(12) Vahel, A.; Hubener, S.; Eichler, B. Radiochim. Acta 1995, 69, 233. 
(13) Vahel, A.; Hubener, S.; Dressler, R.; Eichler, B.; Turler, A. Radiochim. Acta 1997, 78, 53.

(14) Minming, H.; Howe, R. F. J. Catal. 1987, 108, 283.

(15) Liu, W.; Xu, Y.; Wong, S.-T.; Wang, L.; Qiu, J.; Yang, N. J. Mol. Catal. A 1997, 120, 257.

(16) Biscardi, J. A.; Meitzner, G. D.; Iglesia, E. J. Catal. 1998, 179, 192.

(17) H-ZSM5 samples ( $0 \%$ Mo) were heated to higher temperatures (973 $\mathrm{K})$ in order to ensure complete isotopic exchange.

(18) The relaxation delay was $1.0 \mathrm{~s}$, the sweep width was $50 \mathrm{kHz}$, and all chemical shifts were referred to a dilute $\mathrm{Al}\left(\mathrm{NO}_{3}\right)_{3}$ solution. A $90^{\circ} / 180^{\circ}$ echo pulse sequence was used and data were collected for $0.35 \mathrm{~h}$. Increasing the relaxation delay between acquisitions did not increase the ${ }^{27} \mathrm{Al}$ NMR signal, indicating that $1.0 \mathrm{~s}$ was sufficient to allow full relaxation of all $\mathrm{Al}$ spin states. In this case, the NMR signal peak area, integrated using Peakfit (Jandel Scientific), is proportional to the number of $\mathrm{Al}$ centers represented in that peak.

(19) Kentgens, A. P. M.; Scholle, K. F. M. G. J.; Veeman, W. S. J. Phys. Chem. 1983, 87, 4357.

(20) Deng, F.; Du, Y.; Ye, C.; Wang, J.; Ding, T.; Li, H. J. Phys. Chem. 1995, 99, 15208.

(21) Experiments using unheated lines overestimated the amount of carbon deposited on the catalyst because of condensation of naphthalene and heavier products in the gas transfer lines.

(22) HP 6890 gas chromatograph (Hewlett-Packard) equipped with a Carboxen 1000 packed column $(3.2 \mathrm{~mm} \times 2 \mathrm{~m}$, Supelco) connected to a thermal conductivity detector and with a HP-1 capillary column (methyl silicone, $0.32 \mathrm{~mm} \times 50 \mathrm{~m} \times 1.05 \mathrm{~mm}$, Hewlett-Packard) connected to a flame ionization detector.

(23) All gases were $>99.99 \%$ purity (from Praxair and Matheson) and were passed through molecular sieve (13X and 5A) traps before use. Flow rates were metered using electronic mass flow controllers (Porter Instruments).

(24) Wolthuizen, J. P.; van den Berg, J. P.; can Hoof, J. H. C. In Catalysis by Zeolites, Imelik, B., Ed.; Elsevier Scientific Publishing Co.: Amsterdam, 1980

(25) The initial concentration of Mo for this sample was $4.0 \mathrm{wt} \%$, but after temperature-programmed treatment in air up to $973 \mathrm{~K}$ the sample contained 3.6 wt \% Mo (Table 3).

(26) Wang, D.; Lunsford, J. H.; Rosynek, M. P. J. Catal. 1997, 169, 347.

(27) The initial Mo concentration for this sample was $8 \mathrm{wt} \%$, but after temperature-programmed treatment in air the sample contained $6.3 \mathrm{wt} \%$ Mo (Table 3).

(28) Chen, L.; Lin, L.; Xu, Z.; Li, X.; Zhang, T. J. Catal. 1995, 157, 190.

(29) In principle, the number of $D$ atoms counted during $\mathrm{H}_{2}(\mathrm{~g}) / \mathrm{O}(\mathrm{s})-\mathrm{D}$ exchange should equal the number of $\mathrm{H}$ atoms detected during $\mathrm{D}_{2}(\mathrm{~g}) /$ $\mathrm{O}(\mathrm{s})-\mathrm{H}$ exchange. The latter, however, was larger for all samples containing Mo, because more $\mathrm{D}_{2}$ was formed during $\mathrm{H}_{2}(\mathrm{~g}) / \mathrm{O}(\mathrm{s})-\mathrm{D}$ exchange than $\mathrm{H}_{2}$ was during the initial $\mathrm{D}_{2}(\mathrm{~g}) / \mathrm{O}(\mathrm{s})-\mathrm{H}$ exchange. One explanation for this discrepancy is that the mass fragmentation pattern of the $\mathrm{D}_{2} \mathrm{O}$ reduction peak during the first $\mathrm{D}_{2}(\mathrm{~g}) / \mathrm{O}(\mathrm{s})-\mathrm{H}$ exchange contains some $\mathrm{H}_{2} \mathrm{O}$.

(30) This value is less than unity because some acid sites were lost during the conversion of $\mathrm{NH}_{4}-\mathrm{ZSM} 5$ to $\mathrm{H}-\mathrm{ZSM} 5$ at $773 \mathrm{~K}$. This sample also lost additional $\mathrm{O}-\mathrm{H}$ groups during the initial $\mathrm{D}_{2}(\mathrm{~g}) / \mathrm{O}(\mathrm{s})-\mathrm{H}$ exchange, because it required heating to $973 \mathrm{~K}$ in order to complete the isotopic exchange. The $\mathrm{H} / \mathrm{Al}$ values from the second $\mathrm{H}_{2}(\mathrm{~g}) / \mathrm{O}(\mathrm{s})-\mathrm{D}$ exchange were used for Mo-containing samples in the calculations shown in Table 4, because this led to a more accurate hydrogen atom balance.

(31) Zhang, J.-Z.; Long, M. A.; Howe, R. F. Catal. Today 1998, 44 293.

(32) Lunsford, J. H.; Rosynek, M. P.; Wang, D. Presented at the 4th International Natural Gas Symposium, Kruger National Park, South Africa, 1995.

(33) Solymosi, F.; Szoke, A. Symposium on Heterogeneous Hydrocarbon Oxidation, 211th National Meeting, American Chemical Society (New Orleans, LA), 1996; p 147.

(34) Mestl, G.; Knözinger, H. Langmuir 1998, 14, 3964.

(35) Regalbuto, J. R.; Ha, J.-W. Catal. Lett. 1994, 29, 189.

(36) The fact that $\mathrm{MoO}_{x}$ spreading occurs on external ZSM5 surfaces suggests that the $\mathrm{Al}$ content in H-ZSM5 has a high enough surface density of $\mathrm{Al}$ sites to form $\left(\mathrm{MoO}_{x}\right)_{n}$ oligomers that bridge $\mathrm{Al}$ species on the external surface. $\mathrm{Si}-\mathrm{O}-\mathrm{Mo}$ bonds do not appear to be strong enough to survive air treatment at $950 \mathrm{~K}$, since $\mathrm{MoO}_{3}$ vapor exchange preparation (Figure 6) results in only $4.3 \mathrm{wt} \% \mathrm{Mo}$, which is much less than expected if the external ZSM5 surface area was covered and framework $\mathrm{OH}$ groups were exchanged with Mo.

(37) Andersson, G.; Magneli, A. Acta Chem. Scand. 1950, 4, 793.

(38) $\mathrm{MoO}_{3}$ may eventually spread into a monolayer, but below $773 \mathrm{~K}$ the weak bonds between bilayers are more likely to break than the strong $\mathrm{Mo}-\mathrm{O}-\mathrm{Mo}$ bonds within bilayers.

(39) This Mo content (4 wt \%) corresponds to about $19 \mathrm{~m}^{2} / \mathrm{g}$ for a $\mathrm{MoO}_{3}$ bilayer or $38 \mathrm{~m}^{2} / \mathrm{g}$ for a monolayer.

(40) Pope, M. T. Heteropoly and Isopoly Oxometalates; Inorganic Chemistry Concepts; Jorgensen, C. K., Ed.; Springer-Verlag: Berlin, 1983.

(41) Feng, X. B.; Hall, W. K. Catal. Lett. 1997, 46, 11.

(42) The Tammann temperature of quartz $\mathrm{SiO}_{2}$ is $940 \mathrm{~K}$, so mobility of ions in the $\mathrm{O}-\mathrm{Si}-\mathrm{O}$ lattice of ZSM5 should occur between 673 and 973 $\mathrm{K}$.

(43) Engelhardt, G.; Michel, D. High-resolution solid-state NMR of silicates and zeolites; Wiley, New York, 1987.

(44) Borry, R. W.; Li, W.; Meitzner, G.; Iglesia, E. J. Catal. submitted for publication.

(45) Xu, Y.; Liu, W.; Wong, S.-T.; Wang, L.; Guo, X. Catal. Lett. 1996, 40, 207.

(46) Pinglian, T.; Zhusheng, X.; Tao, Z.; Laiyuan, C.; Liwu, L. React. Kinet. Catal. Lett. 1997, 61, 391.

(47) Borry, R. W.; Lu, E. C.; Kim, Y. H.; Iglesia, E. Stud. Surf. Sci. Catal. 1998, 119, 403. 